\title{
Counteraction of Biofilm Formation and Antimicrobial Potential of Terminalia catappa Functionalized Silver Nanoparticles against Candida albicans and Multidrug-Resistant Gram-Negative and Gram-Positive Bacteria
}

\author{
Mohammad Azam Ansari ${ }^{1}\left(\mathbb{D}\right.$, Abul Kalam 2,3,*, Abdullah G. Al-Sehemi ${ }^{2,3} \mathbb{D}$, Mohammad N. Alomary ${ }^{4}(\mathbb{D}$, \\ Sami AlYahya ${ }^{4}$, Mohammad Kashif Aziz ${ }^{5}$, Shekhar Srivastava ${ }^{5}$, Saad Alghamdi ${ }^{6}$ (D), Sultan Akhtar ${ }^{7}$ (D), \\ Hussain D. Almalki ${ }^{8}$, Syed F. Adil ${ }^{9, *(\mathbb{D})}$, Mujeeb Khan ${ }^{9} \mathbb{D}$ and Mohammad R. Hatshan ${ }^{9}$ (D)
}

Citation: Ansari, M.A.; Kalam, A.; Al-Sehemi, A.G.; Alomary, M.N.; AlYahya, S.; Aziz, M.K.; Srivastava, S.; Alghamdi, S.; Akhtar, S.; Almalki, H.D.; et al. Counteraction of Biofilm Formation and Antimicrobial Potential of Terminalia catappa Functionalized Silver Nanoparticles against Candida albicans and Multidrug-Resistant Gram-Negative and Gram-Positive Bacteria. Antibiotics 2021, 10, 725. https:// doi.org/10.3390/antibiotics10060725

Academic Editor: Alberto Vitali

Received: 28 April 2021

Accepted: 11 June 2021

Published: 16 June 2021

Publisher's Note: MDPI stays neutral with regard to jurisdictional claims in published maps and institutional affiliations.

Copyright: (C) 2021 by the authors. Licensee MDPI, Basel, Switzerland. This article is an open access article distributed under the terms and conditions of the Creative Commons Attribution (CC BY) license (https:/ / creativecommons.org/licenses/by/ $4.0 /)$.
1 Department of Epidemic Disease Research, Institute for Research \& Medical Consultations (IRMC), Imam Abdulrahman Bin Faisal University, Dammam 31441, Saudi Arabia; maansari@iau.edu.sa

2 Department of Chemistry, Faculty of Science, King Khalid University, Abha 61413, Saudi Arabia; agsehemi@kku.edu.sa

3 Research Center for Advanced Materials Science (RCAMS), King Khalid University, Abha 61413, Saudi Arabia

4 National Centre for Biotechnology, King Abdulaziz City for Science and Technology (KACST), Riyadh 11442, Saudi Arabia; malomary@kacst.edu.sa (M.N.A.); salyahya@kacst.edu.sa (S.A.)

5 Department of Chemistry, Faculty of Science, University of Allahabad, Allahabad 211001, Uttar Pradesh, India; mohdkashifaziz@allduni.ac.in (M.K.A.); diriids@allduni.ac.in (S.S.)

6 Laboratory Medicine Department, Faculty of Applied Medical Sciences, Umm Al-Qura University, Makkah 24231, Saudi Arabia; ssalghamdi@uqu.edu.sa

7 Department of Biophysics, Institute for Research \& Medical Consultation (IRMC), Imam Abdulrahman Bin Faisal University, Dammam 31441, Saudi Arabia; suakhtar@iau.edu.sa

8 Department of Chemistry, University College in Al-Qunfudah, Umm Al-Qura University, Makkah Al-Mukarramah 1109, Saudi Arabia; hdmalki@uqu.edu.sa

9 Department of Chemistry, College of Science, King Saud University, Riyadh 11451, Saudi Arabia; kmujeeb@ksu.edu.sa (M.K.); mhatshan@ksu.edu.sa (M.R.H.)

* Correspondence: abulkalam@kku.edu.sa (A.K.); sfadil@ksu.edu.sa (S.F.A.)

Abstract: Biofilms not only protect bacteria and Candida species from antibiotics, but they also promote the emergence of drug-resistant strains, making eradication more challenging. As a result, novel antimicrobial agents to counteract biofilm formation are desperately needed. In this study, Terminalia catappa leaf extract (TCE) was used to optimize the TCE-capped silver nanoparticles (TCE-AgNPs) via a one-pot single-step method. Varied concentrations of TCE have yielded different sized AgNPs. The physico-chemical characterization of TCE-AgNPs using UV-Vis, SEM, TEM, FTIR, and Raman spectroscopy have confirmed the formation of nanostructures, their shape and size and plausible role of TCE bio-active compounds, most likely involved in the synthesis as well as stabilization of NPs, respectively. TCE-AgNPs have been tested for antibiofilm and antimicrobial activity against multidrug-resistant Pseudomonas aeruginosa (MDR-PA), methicillin-resistant Staphylococcus aureus (MRSA), and Candida albicans using various microbiological protocols. TCE-Ag-NPs-3 significantly inhibits biofilm formation of MDR-PA, MRSA, and C. albicans by 73.7, 69.56, and 63.63\%, respectively, at a concentration of $7.8 \mu \mathrm{g} / \mathrm{mL}$, as determined by crystal violet microtiter assay. Furthermore, SEM micrograph shows that TCE-AgNPs significantly inhibit the colonization and adherence of biofilm forming cells; individual cells with loss of cell wall and membrane integrity were also observed, suggesting that the biofilm architecture and EPS matrix were severely damaged. Moreover, TEM and SEM images showed that TCE-AgNPs brutally damaged the cell wall and membranes of MDR-PA, MRSA, and C. albicans. Additionally, extreme ultrastructural changes such as deformation, disintegration, and separation of cell wall and membrane from the cells, have also been observed, indicating significant loss of membrane and cell wall integrity, which eventually led to cell death. Overall, the research revealed a simple, environmentally friendly, and low-cost method for producing colloidal TCE-AgNPs with promising applications in advanced clinical settings against broad-spectrum biofilm-forming antibiotic-resistant bacteria and candida strains. 
Keywords: biofilm; antibiotics resistant; bio-actives capping; silver nanoparticles; TEM; ultrastructural changes; Candida albicans; MRSA

\section{Introduction}

The Gram-negative multidrug-resistant Pseudomonas aeruginosa (MDR-PA) and Grampositive methicillin-resistant Staphylococcus aureus (MRSA) human pathogens are the leading causes of nosocomial infections in hospitals globally [1,2]. In the same line, colonization of Candida albicans in urinary catheters and endotracheal tubes implanted in immunocompromised patients indicates the alarming frequency of fungal infections [3,4]. Matured biofilms of MDR-PA, MRSA, and C. albicans are comprised of a complex three-dimensional structure of multiple stacked layers and aggregated clusters of their cells, hyphae, extracellular DNA, proteins, and abundant exopolysaccharide (EPS) matrix [5-7]. Establishment and maturation of biofilms of such microbial pathogens on a number of medical devices such as dental restorative fillings, orthopedic implants, contact lenses, and catheters have been accounted majorly for the failure of biomaterial-based medical implants and traditional antibiotics. Thus, the menace of antimicrobial resistance (AMR) in biofilms has fueled the hospital acquired infections further. To control microbial biofilms, a variety of medicinal crude extracts and essential oils containing bio-active carbohydrates, terpenoids, polyphenols, alkaloids, phenolic acids, and proteins have been used as well as these bioactives-capped metal nanoparticles have been employed such as potential antimicrobial, antibiofilm, and antiquorum sensing agents [8,9].

Nanoparticles (NPs) are referred to as structures that possess at least one of its dimensions less than $100 \mathrm{~nm}$. Such nanoscale fabrication of organic, inorganic, metallic, and biological structures is generally done by following either bottom-up or top-down approaches. In modern times, green approaches for NPs synthesis have gained immense interest due to its eco-friendly processing and low-cost input [10-12]. Furthermore, NPs derived from various plant extracts contain a variety of indigenous bio-active molecules such as polyphenols, alkaloids, terpenoids, sugars, proteins, and enzymes that act as reducing, capping, and stabilizing agents. Among the various plants reported for the fabrication of NPs is the Terminalia catappa plant, which has been popularly known as a folk medicine due to its promising therapeutic effects against dermatitis and hepatitis in India and the Philippines [13]. It has been found that Terminalia catappa leaf extract (TCE) contains alkaloids, celluloses, flavonoids, lignins, triterpenoids, as principal bio-actives molecules, which can be regarded for their anticancer, antibacterial, and antioxidant activities [14-18]. The bio-active compounds present in T. catappa leaf extract (TCE) were reported as an excellent recipe for TCE mediated bio-reduction of $\mathrm{Au}^{4+}, \mathrm{Cu}^{2+}, \mathrm{Ti}^{4+}$, and $\mathrm{Nd}^{3+}$ to $\mathrm{Au}, \mathrm{Cu}$ $\mathrm{TiO}_{2}$, and $\mathrm{Nd}_{2} \mathrm{O}_{3} \mathrm{NPs}$, respectively, wherein the extract functions as an excellent reducing and stabilizing agent [19-23]. However, despite the above reported protocols employed for the nanoscale fabrication of various metallic salts, silver which is usually the first choice among metallic nanomaterial fabrication due to its well-established microbicidal property, is yet to be prepared at nanoscale using T. catappa leaf extract (TCE) [24].

The antimicrobial potential of silver nanoparticles (Ag-NPs) is being investigated and is widely regarded as one of the most promising nanoantibiotics. This is due to interactions between $\mathrm{Ag}^{+}$and cysteine moieties rich domains of cell proteins, which promote the loss of membrane potential through $\mathrm{K}^{+}$loss, disrupting cellular transport and respiratory systems, and ultimately leading to bacterial death [25]. Chemical, physical, and green methods can be used to produce AgNPs. The resultant nanoparticles have a variety of properties (surface chemistry, shape, and size) that affect their capacity to combat bacteria and fungi [26]. They represent a new research approach that focuses on a new class of materials with prospective applications in the biomedical, biological, and pharmaceutical fields, and they have shown considerable promise and implications in the treatment of bacterial infections. Combining AgNPs with modest amounts of 
antibiotics has been suggested to boost their antimicrobial efficacy, providing outstanding results in vitro, and so holding potential for efficient in vivo bacterial eradication [26]. These nanoparticles and their ions exert antimicrobial activity by causing damage to the biofilm structure and components, as well as impairing bacterial metabolism via a variety of mechanisms [27]. These nanoparticles approach the biofilm, penetrate it, migrate internally, and interact with key biofilm components such as polysaccharides, lipids, proteins, and nucleic acids via hydrogen-bonding, electrostatic, ionic hydrophobic, Van der Waals interactions, while exerting antimicrobial activity [27]. AgNPs based on cyclophanes have recently been employed to recognize a wide range of biomolecules in aqueous conditions, including hydroxyl acids, amino acids, proteins, and nucleic acids. Colorimetric and electrochemical sensors based on cyclophane-capped AgNPs were also developed for the selective measurement of heavy metal cations, anions, various amino acids, pesticides, and polycyclic aromatic hydrocarbons. Cyclophane-capped AgNPs have shown promise in medicine and diagnostics [28]. At low doses, $\mathrm{Ag}^{+}$ions show excellent biocompatibility with mammalian cells and are therefore often regarded as environmentally friendly [29]. Besides, bacteria against free $\mathrm{Ag}^{+}$exhibit weak ability to augment resistance, which in fact offers a broad scope to explore alternatives for advanced antimicrobial formulations development against the rapidly growing antimicrobial resistance (AMR) globally [30].

Hence, with the aforementioned potentials of AgNPs and TCE bio-actives, the objective of the present study was: (i) Biofabrication of stable TCE-AgNPs by employing one step bio-inspired method; (ii) characterization of biosynthesised TCE-AgNPs by UV-Vis spectrophotometer, Fourier transform infrared (FTIR), Raman spectroscopy, transmission electron microscope (TEM), and scanning electron microscope (SEM); (iii) Investigation of antimicrobial activities of TCE-Ag-NPs against Gram-negative multidrug resistant $P$ seudomonas aeruginosa (MDR-PA), Gram-positive methicillin resistant Staphylococcus aureus (MRSA), and yeast Candida albicans by broth dilution and well diffusion methods; (iv) Investigation of antibiofilm potential of TCE-Ag-NPs against MDR-PA, MRSA, and C. albicans by 96-well microtiter crystal violet assay; (v) Assessment of the effect of TCE-AgNPs on biofilm structure of tested strains by SEM; and (vi) Interaction and visualization of ultrastructural alteration caused by TCE-AgNPs in MDR-PA, MRSA, and C. albicans by SEM and TEM.

\section{Materials and Methods}

\subsection{Preparation of T. catappa Leaf Extract (TCE)}

The fresh leaves of T. catappa were washed with sterile de-ionized water and air-dried. The dried T. catappa leaves were ground into fine powder by using domestic mortar pastel. Then, $5 \mathrm{~g}$ of $T$. catappa powder was added to $100 \mathrm{~mL}$ of sterilized de-ionized water vortexed vigorously, and then boiled for $20 \mathrm{~min}$ on a heating plate. The cooled solution was filtered by Whatman No. 1 paper and stored at $4{ }^{\circ} \mathrm{C}$ for future use.

\subsection{Bio-Synthesis of TCE-Ag-NPS}

The synthesis of TCE-NPs was carried out by following the method detailed elsewhere [31]. Precisely, 1, 2, and $5 \mathrm{~mL}$ aqueous TCE were added to 9,8 , and $5 \mathrm{~mL}$ of silver nitrate $\mathrm{AgNO}_{3}$ (Sigma Aldrich, St. Louis, MO, USA), respectively, to achieve a final concentration of $0.01 \mathrm{M} \mathrm{AgNO}_{3}$ in $10 \mathrm{~mL}$ of each reaction mixer. At room temperature $\left(25-30{ }^{\circ} \mathrm{C}\right)$, the three experimental solutions began to develop an increased gradient of brown color after 30, 25, and 15 min function of TCE concentration as compared to the pale yellow solution observed at zero time. The solutions were spun at 14,000 rpm for $10 \mathrm{~min}$ to obtain precipitated TCE-Ag-NPs. The pelleted TCE-Ag-NPs were washed with ethanol and dried at $60^{\circ} \mathrm{C}$ to obtain powder TCE-Ag-NPs. The Ag NPs obtained from the reaction mixtures containing 1, 2, $5 \mathrm{~mL}$ of TCE were designated as TCE-Ag-1, TCE-Ag-2, and TCE-Ag-3, respectively. The TCE-Ag-NPs were stored in the dark to investigate the physico-chemical and antimicrobial properties. 


\subsection{Physico-Chemical Characterization of TCE-Ag-NPs}

\subsubsection{UV-Visible Spectroscopy}

The formation of TCE-Ag-1, TCE-Ag-2, and TCE-Ag-3 NPs in formulations was monitored by detecting characteristic SPR of nano silver in the range of $200-700 \mathrm{~nm}$ on a UV-Vis spectrophotometer (PG Instruments Ltd., Alma Park, Wibtoft, Leicestershire, UK).

\subsubsection{FTIR Spectroscopy of TCE-Ag-3}

FT-IR (Cary 630 Agilent, Stevens Creek Blvd., Santa Clara, CA, USA) was employed to identify and compare the functional groups of bio-actives present in pristine TCE as well as adsorbed on the surface of TCE-Ag-3. In brief, dried T. catappa leaves powder and TCE-Ag-3 were mixed with $\mathrm{KBr}$ separately and the spectra were recorded in the range of 4000 and $400 \mathrm{~cm}^{-1}$ at room temperature with a resolution of $4 \mathrm{~cm}^{-1}$ [32].

\subsubsection{Raman Spectroscopy of TCE-Ag-3}

The Raman spectrum of TCE-Ag-3 was collected by using Inspector Raman (DXR, Thermo Fisher Scientific, Madison, WI, USA) with a $785 \mathrm{~nm}$ laser diode, a $200-2000 \mathrm{~cm}^{-1}$ spectral range, and a $15 \mathrm{~cm}^{-1}$ resolution. The value of the most intense band in the spectrum of TCE-Ag-3 analyzed by processing crude data with the Sigma Plot version 11.2 (Systat Software, Inc., San Jose, CA, USA) data analysis software.

\subsubsection{Electron Microscopy-Based Analyses of TCE-Ag-NPs}

The morphological properties of TCE-Ag-1, TCE-Ag-2, and TCE-Ag-3 nano formulations were explored by using a scanning electron microscope (SEM, JSM-6610LV, JEOL, Tokyo, Japan), at an accelerating voltage between 10 and $20 \mathrm{kV}$ by following the protocol described elsewhere [8]. Besides, the morphology and size of TCE-Ag-1, TCE-Ag-2, and TCE-Ag-3 nano formulations were further explored based on transmission electron microscopy (TEM; Morgagni 268, FEI, Brno-Černovic, Czech Republic). The size of three TCE-Ag-NPs formulations was further analyzed by processing the TEM images with the Image J1 (University of Wisconsin, Madison, WI, USA) multidimensional image processing software.

\subsection{Antibacterial Activities of TCE-Ag-NPs}

\subsubsection{Assessment of Antibacterial Activities of TCE-Ag-NPs by Well Diffusion Assay}

TCE-Ag-1, TCE-Ag-2, and TCE-Ag-3 NPs formulations were assessed for their antibacterial activity. Concisely, $100 \mu \mathrm{L}$ of exponentially growing $\left(1 \times 10^{7}\right.$ colony forming unit (CFU)/mL) MR-S. aureus (MRSA) and MDR-P. aeruginosa (MDR-PA) were spread on Luria-Bertani agar (LBA) plates. Whereas, C. albicans cells $\left(5 \times 10^{6} \mathrm{CFU} / \mathrm{mL}\right)$ were evenly spread on Sabouraud Dextrose agar (SDA) plates. The LBA and SDA layers in the plates were punched with a sterilized stub to create wells with a diameter of $6 \mathrm{~mm}$. Soft agar $(0.7 \%)$ was added to all the wells to seal the bottom leakage prior to adding nano formulations. A fixed volume i.e., $100 \mu \mathrm{L}$ of TCE-Ag-1, TCE-Ag-2, and TCE-Ag-3 NPs formulations were added into the wells of MRSA, MDR-PA, and C. albicans plates separately. The zone of growth inhibition (ZOI) was determined by considering the diameter of zones after incubating the plates at $37^{\circ} \mathrm{C}$ for $24 \mathrm{~h}$.

2.4.2. Determination of MIC, MBC and MFC Values of TCE-Ag-NPs against Test Bacterial and Fungal Strains

The determination of minimum inhibitory concentration (MIC), minimum bactericidal concentration (MBC), and minimum fungicidal concentration (MFC) values of TCE-Ag1, TCE-Ag-2, and TCE-Ag-3 NPs formulations against MRSA, MDR-PA, and C. albicans strains were determined following the two-fold serial dilution procedure, described by Ansari et al. [33]. Briefly, the bacterial inoculums of $\sim 1 \times 10^{7} \mathrm{CFU} / \mathrm{mL}$ were treated with TCE-Ag-1, TCE-Ag-2, TCE-Ag-3 NPs in a concentration range of 3.90 to $500 \mu \mathrm{g} / \mathrm{mL}$. In the case of $C$. albicans, MIC and MFC values were determined from 31.25 to $250 \mu \mathrm{g} / \mathrm{mL}$ 
of TCE-Ag-NPs. The treated and untreated control tubes with bacterial and C. albicans strains were incubated for $24 \mathrm{~h}$ at 37 and $28^{\circ} \mathrm{C}$, respectively. The MIC was defined as the lowest concentration of antimicrobial agents that yielded no visible growth of the microorganisms [33]. For MBC/MFC determination, $100 \mu \mathrm{L}$ aliquots from the culture tubes in which no visible growth was observed were spread on the LBA and SDA plates. The plates were then incubated for $24 \mathrm{~h}$ at 37 and $28^{\circ} \mathrm{C}$, respectively. The MBC/MFC endpoint is defined as the lowest concentration of antimicrobial agent that kills $100 \%$ of the initial microbial population [10].

\subsubsection{SEM Based Imaging of Test Strains and TCE-Ag-3}

Significant higher antimicrobial activity of TCE-Ag-3 as compared to TCE-Ag-2 and TCE-Ag-1 formulations prompted us to investigate the TCE-Ag-3 induced morphological damages in planktonic cells of test strains. Hence, SEM imaging was performed with the MIC values of TCE-Ag-3 for MRSA, MDR-PA, and C. albicans cells. The untreated control and treated cells of test strains were incubated with TCE-Ag-3 for $24 \mathrm{~h}$ at $37^{\circ} \mathrm{C}$. Thereafter, cells spun at $5000 \mathrm{rpm}$ for $5 \mathrm{~min}$ and incubated in glutaraldehyde $(2.5 \%)$ at $4{ }^{\circ} \mathrm{C}$ for $4 \mathrm{~h}$. The fixed cells were then incubated in 30\%, 50\%, 70\%, and 90\% ethanol for $15 \mathrm{~min}$, consecutively. Then, $100 \mu \mathrm{L}$ of each sample was uniformly spread on cleaned glass covers separately, dried at room temperature, sputter coated with gold, and finally examined by SEM (JSM-6610LV, JEOL, Tokyo, Japan).

\subsubsection{TEM Based Assessment of Antimicrobial Activity of TCE-Ag-3}

The results of the SEM were confirmed by TEM analysis, as discussed elsewhere [10]. Briefly, MRSA, MDR-PA, and C. albicans cells grown in the presence of MIC values of TCE-Ag-3 were centrifuged, washed with MQ water, fixed in $2.5 \%$ glutaraldehyde and $1 \%$ osmium tetraoxide, and embedded in Epon resin (Polybed 812). So prepared blocks of cells were sectioned, stained with uranyl acetate and lead citrate (Sigma Aldrich, St. Louis, MO), and imaged on TEM (Morgagni 268, FEI, Czech Republic) with accelerating voltage of $80 \mathrm{kV}$.

\subsubsection{Evaluation of Antibiofilm Activity of TCE-Ag-3 against Test Strains}

The 96-well microtiter plate method was used to evaluate the antibiofilm activity of TCE-Ag-3 NPs against MRSA, MDR-PA, and C. albicans [10]. Precisely, the wells seeded with $100 \mu \mathrm{L}$ of bacteria $\left(\sim 1 \times 10^{7} \mathrm{CFU} / \mathrm{mL}\right)$ and C. albicans $\left(\sim 5 \times 10^{6} \mathrm{CFU} / \mathrm{mL}\right)$ were treated with $0.95,1.95,3.90$, and $7.8 \mu \mathrm{g} / \mathrm{mL}$ of TCE-Ag-3 at $37^{\circ} \mathrm{C}$ for $24 \mathrm{~h}$. The wells were washed with phosphate buffer saline (PBS) after taking out the NPs suspensions. Subsequently, $200 \mu \mathrm{L}$ of crystal violet (CV, $0.25 \%$ ) was added for $30 \mathrm{~min}$. The wells were washed, air dried, and filled with 95\% ethanol to solubilize the biofilm bound CV. The absorbance was read at $595 \mathrm{~nm}$ by using a microplate reader.

\subsubsection{Effect of TCE-Ag-3 on Biofilm Structure of Tested Strains}

In parallel, the destruction of biofilms matrices was analyzed by SEM following the protocol described in Section 2.4.3. Briefly, the biofilms adhered on the glass covers after $24 \mathrm{~h}$ of the treatment of TCE-Ag-3 $(7.8 \mu \mathrm{g} / \mathrm{mL})$ were fixed in $2.5 \%$ glutaraldehyde at $4{ }^{\circ} \mathrm{C}$ and dehydrated with 30\%,50\%, 70\%, and 90\% ethanol for $15 \mathrm{~min}$, consecutively. The biofilms were coated with gold sputtering before capturing the SEM micrographs.

\section{Results and Discussion}

\subsection{T. catappa Leaf Extract (TCE) Mediated Synthesis of Ag-NPs}

The role of bio-actives molecules contributed by animal, microbial, and plant cells and tissues in bio-inspired nanomaterial synthesis has been recognized, with the ultimate potential to reduce a wide range of metal cations to nano size particles [34-36]. Benign extracts of explants such as leaves, root, stem, bark, and seed typically act as bio-factory for the synthesis of a wide range of bio-actives including long and short hydrocarbon 
chains (saturated/unsaturated), aromatic complex cyclic compounds, polyphenols, alkaloids, flavonoids, terpenoids, sugars, proteins, and enzymes naturally $[8,10,30,31]$. Besides, easy availability, inexpensiveness, low toxicity, and indigenous therapeutic effects of plant bio-actives have attracted the nanotechnologies towards green synthesis approaches while developing their intended nanoconstructs. Albeit, T. catappa leaf extract (TCE) was investigated for TCE-capped Ag NPs. The inset in Figure 1 exhibited a steady change in color of aqueous TCE and $\mathrm{AgNO}_{3}$ (1:1) reaction mixture from pale yellow to dark brown after $15 \mathrm{~min}$ at $37^{\circ} \mathrm{C}$, which is regarded as a preliminary indication of TCE-Ag-NPs formation. This change in color was likely due to collective oscillation of conduction electrons of TCEAg-NPs produced in TCE-Ag-1, TCE-Ag-2, and TCE-Ag-3 reaction mixture, which darkens steadily with their age [37]. Compared to pristine TCE, the appearance of sharp peaks at 488,482 , and $434 \mathrm{~nm}$ in UV-vis spectra (Figure 1) can be assigned to SPR, developed by TCE bio-actives mediated reduction of $\mathrm{Ag}^{+}$in reaction mixtures, respectively. At the same time, the formation of TCE-Ag-1, TCE-Ag-2, and TCE-Ag-3 can be regarded as a function of concentration of TCE. The increase in TCE concentration accelerated the reduction rate of $\mathrm{Ag}^{+}$in reaction mixtures of TCE-Ag-1, TCE-Ag-2, and TCE-Ag-3, respectively. Furthermore, the isotropy in the nascent particle's spherical shape and homogeneous distribution with no agglomeration was justified by a single SPR band in nano formulations, which can be attributed to efficient capping of TCE bio-actives around NPs.

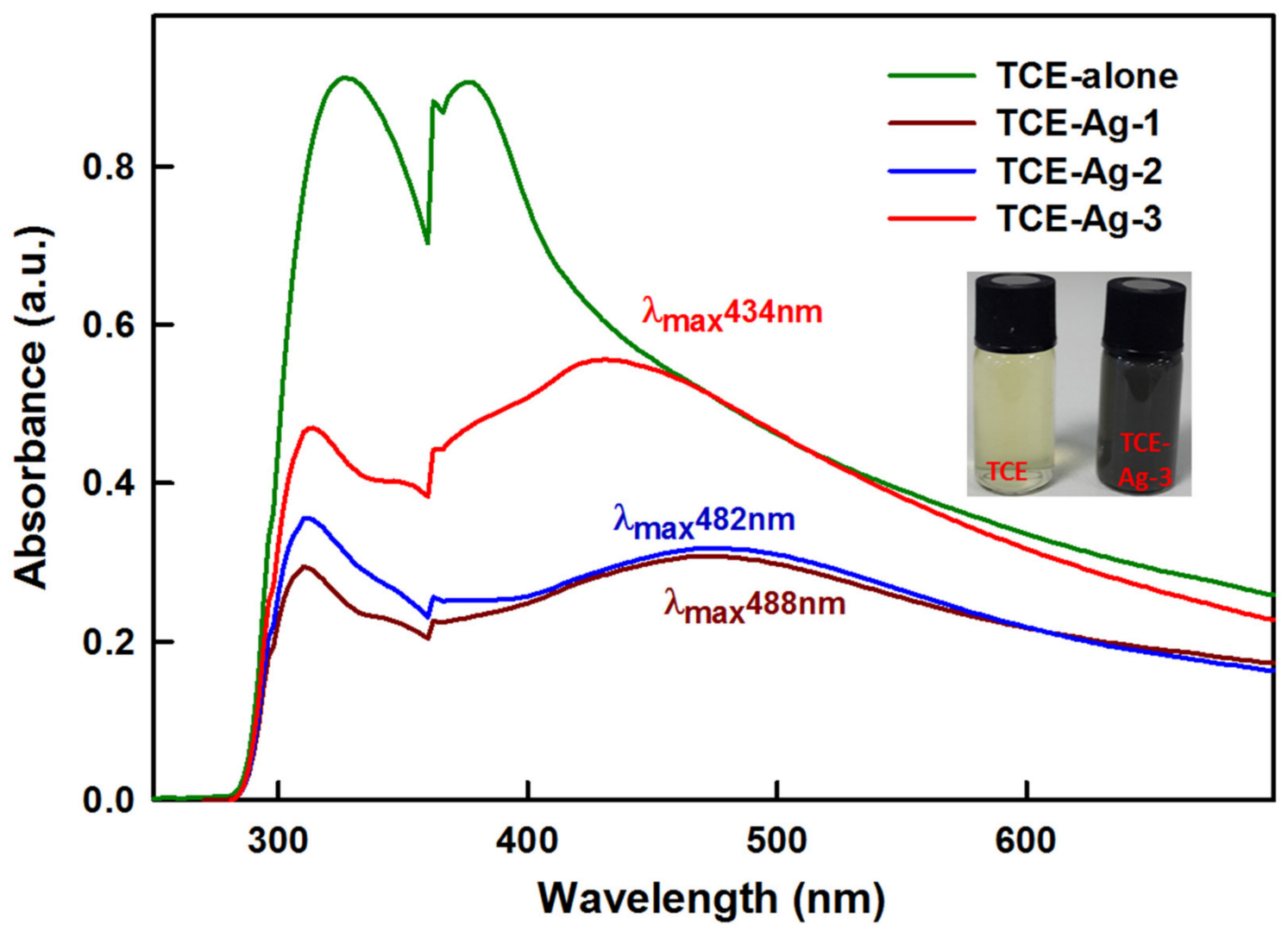

Figure 1. UV-vis analysis of synthesized TCE-Ag-NPs. The inset demonstrates the change in color of the reaction mixture from light yellow to dark brown nano Ag colloidal solution.

\subsection{FTIR Spectral Analysis of TCE-Ag-3}

The FTIR spectra in Figure 2 demonstrated the characteristic vibrational/bending signatures of functional groups associated with bio-active moieties in the pristine TCE as well as adsorbed on Ag-NPs surface. The comparison of TCE and TCE-Ag-3 FTIR spectra indicates the involvement and potential role of bioactive molecules of TCE in AgNPs synthesis, capping, and stability. Strictly, the appearance of sharp bands between 
2800 and $3700 \mathrm{~cm}^{-1}$ is likely due to stretching of aromatic, aliphatic $\mathrm{H}$-bonded $-\mathrm{OH}$, and polymeric -OH stretching and $\mathrm{C}-\mathrm{O}$ groups present in TCE corona around TCE-Ag-3 [38]. Besides, vibrational signals around 1634, 1250,1110, and $675 \mathrm{~cm}^{-1}$ correspond to the involvement of amide-I associated $\mathrm{C}=\mathrm{O}$ group, $\mathrm{C}-\mathrm{H}$, and $\mathrm{O}-\mathrm{H}$ groups deformation and bending of C-H bonds, respectively. Overall, the FTIR spectral signatures reflects the role of bio-actives phenolic carboxylic and alkene TCE in $\mathrm{Ag}^{+}$reduction and encapsulation of nascent TCE-Ag-3 [39-41].

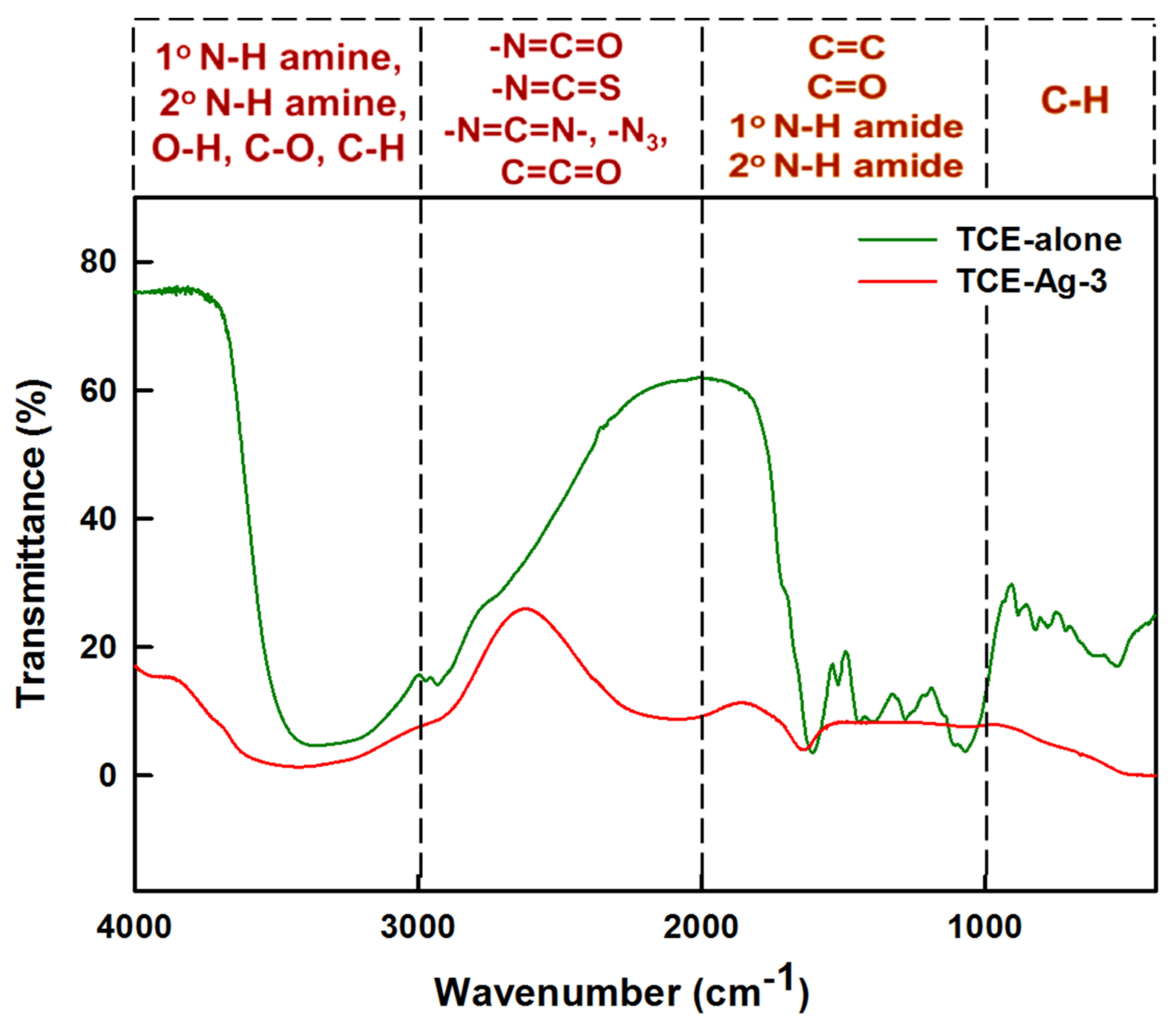

Figure 2. Comparison of FTIR spectra of TCE and TCE-capped Ag-3.

\subsection{Raman Spectral Analysis of TCE-Ag-3}

In addition to FTIR, Raman spectroscopy was also used to examine the functional groups involved in the synthesis and stabilization of the as-prepared TCE-Ag-3 NPs. In fact, Raman spectroscopy relies on quenching of fluorescent bio-actives molecules by using metallic NPs to amplify the Raman signal [42]. Interestingly, earlier Raman spectroscopy reports suggest that -OH group positioned at 3 in flavonoids is most reactive in the presence of Ag-NPs and prompts native flavonoids to change their chemical structure readily [43]. The spectrum obtained from TCE-Ag-3 with the $785 \mathrm{~nm}$ laser was very similar to those obtained by Garcia-Bucio et al. [44]. The bands at 1570, 1372, 946, 622, and $465 \mathrm{~cm}^{-1}$ in Figure 3 are pretty similar to those that have been reported for flavones like morin $\left(\mathrm{C}_{15} \mathrm{H}_{10} \mathrm{O}_{7}\right)$ corresponding to the bands at 1570 and $1372 \mathrm{~cm}^{-1}$, luteolin $\left(\mathrm{C}_{15} \mathrm{H}_{10} \mathrm{O}_{6}\right)$ corresponding to 946 and $465 \mathrm{~cm}^{-1}$, and chrysin $\left(\mathrm{C}_{15} \mathrm{H}_{10} \mathrm{O}_{4}\right)$ corresponding to $622 \mathrm{~cm}^{-1}$ in extract of Cuscuta tinctoria and T. catappa [43-45]. Jones et al. [46] have regarded certain 
bio-actives molecules viz quercetin, luteolin, phloretin, and morin as health beneficial flavonoids found in commonly consumed plant-based products. Morin, in the extracts of almond whole seed, brown skin, and green shell cover extracts, has been reported as a major flavonoid [47]. Harnly et al. [48] also reported the flavone, namely luteolin, in a significant amount in the extract of nuts and almond. Chrysin, a flavone, has not been reported before in almond extract, however, it is present in some natural products such as sunflower honey, propolis [49]. However, functional group bond behaviors present a parallel scenario, as summarized in Table 1 . The two prominent broad peaks at 1570 and $1372 \mathrm{~cm}^{-1}$ correspond to $\mathrm{C}=\mathrm{C}$ and $\mathrm{C}=\mathrm{O}$ stretching vibrations at ring $\mathrm{B}$ and $\mathrm{A}$ rings of morin $\left(\mathrm{C}_{15} \mathrm{H}_{10} \mathrm{O}_{7}\right)$ [41], whereas feeble signals at 946 and $465 \mathrm{~cm}^{-1}$ correspond to cyclic $\mathrm{CH}$ and $\mathrm{COH}$ bending in luteolin $\left(\mathrm{C}_{15} \mathrm{H}_{10} \mathrm{O}_{6}\right)$ structure [50]. The signals at $622 \mathrm{~cm}^{-1}$ correspond to $\delta(\mathrm{CCO})$ and $\delta(\mathrm{COC})$ vibrations in chrysin $\left(\mathrm{C}_{15} \mathrm{H}_{10} \mathrm{O}_{4}\right)$ rings [44]. Whereas, the weak signal at $213 \mathrm{~cm}^{-1}$ can be assigned to the $\mathrm{Ag}-\mathrm{N}$ and $\mathrm{Ag}-\mathrm{O}$ bonds stretching $[50,51]$.

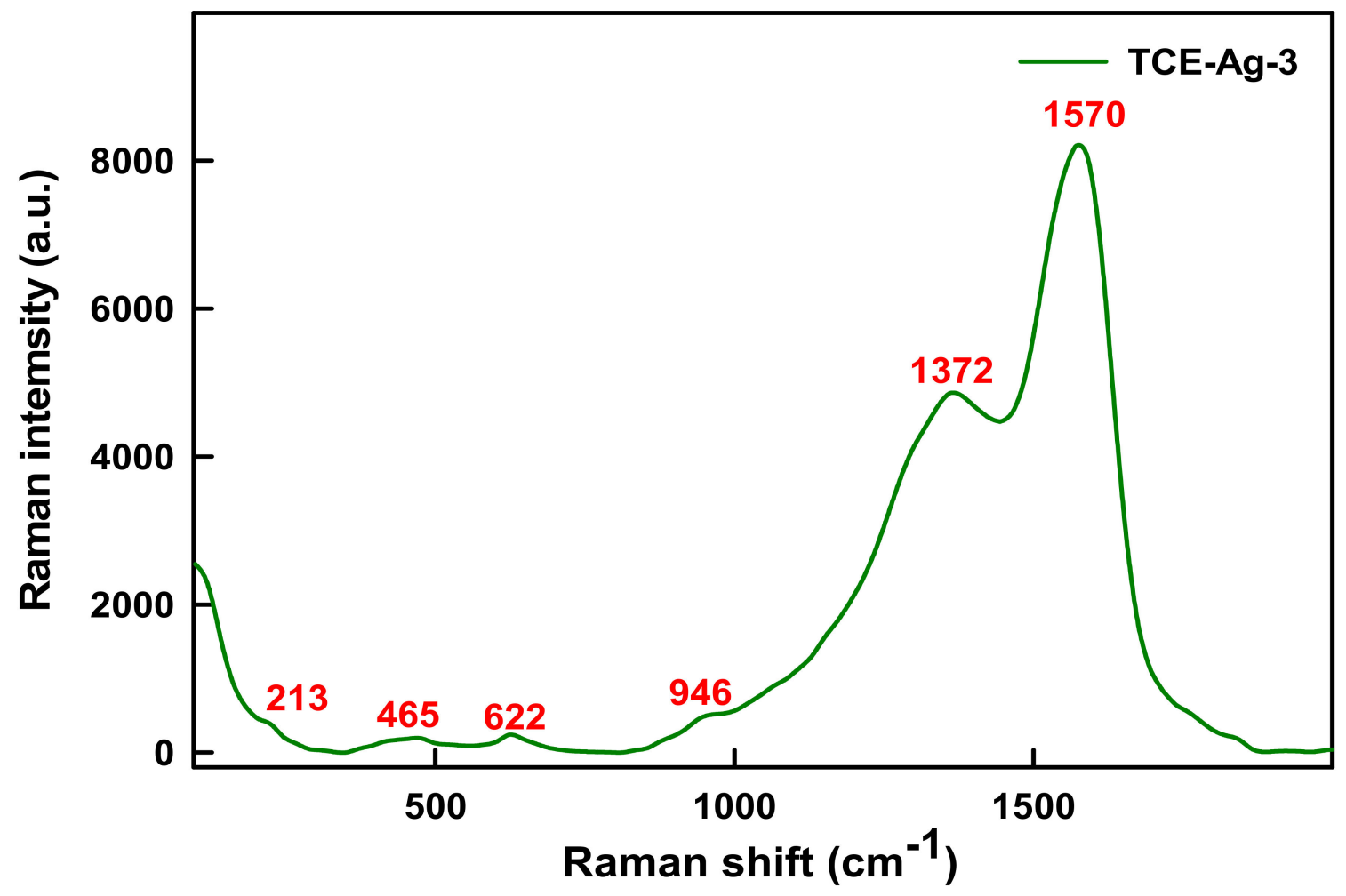

Figure 3. Raman spectroscopic analysis of TCE bio-actives plausibly capped of TCE-Ag-3.

Table 1. Band positions from TCE-Ag-3 colloidal solution at $785 \mathrm{~nm}$ laser wavelength.

\begin{tabular}{|c|c|c|c|c|}
\hline Sample & $\begin{array}{c}\text { Band Wave } \\
\text { number/cm }\end{array}$ & Plausible Bond Assignments & $\begin{array}{c}\text { Plausible TCE } \\
\text { Bio-Active Molecules } \\
\text { on NPs Surface }\end{array}$ & References \\
\hline \multirow{6}{*}{ TCE-Ag-3 } & 1570 & $\mathrm{C}=\mathrm{C}$ of ring $\mathrm{B}$ vibrations & Morin $\left(\mathrm{C}_{15} \mathrm{H}_{10} \mathrm{O}_{7}\right)$ & {$[43,44,47]$} \\
\hline & 1372 & $\mathrm{C}=\mathrm{O}$ of ring $\mathrm{A}$ vibrations & Morin $\left(\mathrm{C}_{15} \mathrm{H}_{10} \mathrm{O}_{7}\right)$ & {$[43,44,47]$} \\
\hline & 946 & cyclic ring bend, cyclic $\mathrm{CH}, \mathrm{COH}$ bend & Luteolin $\left(\mathrm{C}_{15} \mathrm{H}_{10} \mathrm{O}_{6}\right)$ & {$[44,45,48,50]$} \\
\hline & 622 & $\delta(\mathrm{CCO})$ and $\delta(\mathrm{COC})$ vibrations & Chrysin $\left(\mathrm{C}_{15} \mathrm{H}_{10} \mathrm{O}_{4}\right)$ & {$[44]$} \\
\hline & 465 & $\begin{array}{l}\text { Cyclic } \mathrm{CH}, \mathrm{COH} \text { bend, } \mathrm{CO}(\mathrm{H}) \mathrm{Ag} \\
\text { bend, and } \mathrm{CO}_{2} \text { twist }\end{array}$ & Luteolin $\left(\mathrm{C}_{15} \mathrm{H}_{10} \mathrm{O}_{6}\right)$ & {$[44,45,48]$} \\
\hline & 213 & Ag-O vibrations & Unassigned & [50] \\
\hline
\end{tabular}




\subsection{Morphological Characterization of TCE-Ag-NPs}

As prepared, colloidal formulations of TCE-Ag-1, TCE-Ag-2, and TCE-Ag-3 were analyzed by SEM and TEM in order to assess the shape and size of NPs. The SEM micrographs in Figure 4 demonstrate that the TEC-Ag-NPs were in pleomorphic shapes with a predominant number of spherical particles. Precisely, SEM micrograph of TCE-Ag-1 (Figure 4A) revealed the significant large size and irregular shapes of NPs, which is likely due to steady agglomeration after nucleation in the presence of least concentration of TCE $(1 \mathrm{~mL})$ bio-actives. However, as the ratio of capping bio-actives increased, i.e., 2 and $5 \mathrm{~mL}$ in the reaction mixtures of TCE-Ag-3 and TCE-Ag-3, the time of reaction and size of NPs were found to have reduced significantly, respectively. Besides, the SEM results presented in Figure 4B,C also revealed the presence of well diversed and spherical shaped NPs in TCE-Ag-2 and TCE-Ag-3 formulations, respectively. This increased dispersity of NPs in colloidal solutions can be argued as a result of significant capping of TCE bio-actives around nascent NPs which may have controlled the particle's growth and agglomeration. Recently, Ranoszek-Soliwoda et al. [52] also demonstrated a similar pattern in size and agglomeration reduction in Ag-NPs with an increase in sodium citrate concentrations.
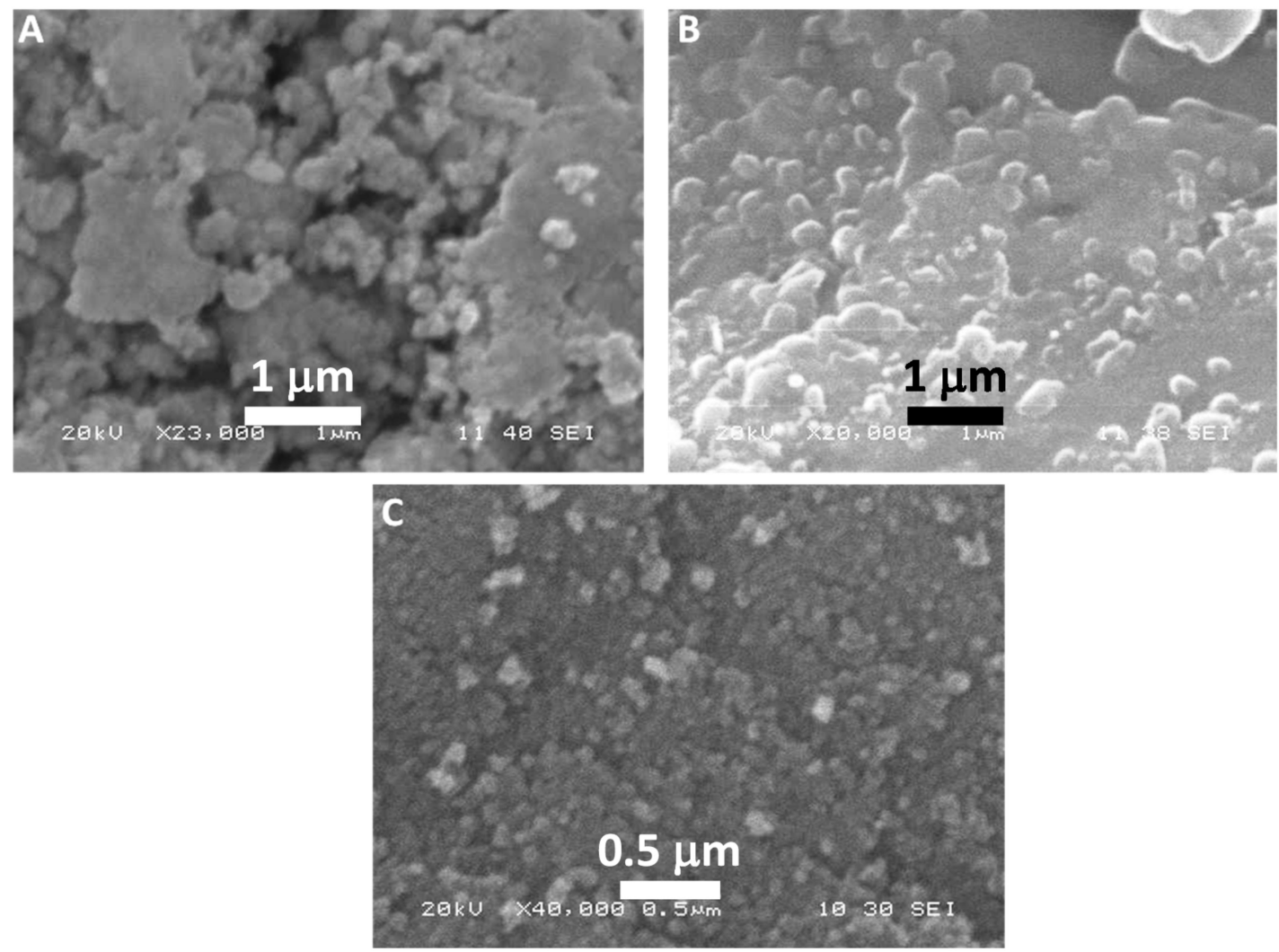

Figure 4. SEM-based comparative analysis of morphologies of TCE-Ag-1 (A), TCE-Ag-2 (B), and TCE-Ag-3 (C) NPs.

Similarly, TEM micrographs of TCE-Ag-1, TCE-Ag-2, and TCE-Ag-3 were also found in good agreement with SEM results. Compared to TCE-Ag-1 (Figure 5(Ai)), TEM images of TCE-Ag-2 (Figure 5(Bi)) and TCE-Ag-3 (Figure 5(Ci)) revealed a clear-cut reduction in size and agglomeration while maintaining their spherical shape. Nascent Ag-NPs formed at an early age of the reaction ultimately act as building-block of large NPs while growth proceeds. Whereas, considering the reaction phases (viz reduction, nucleation, growth, and stabilization), a point of time can be speculated during reduction where complex of $\mathrm{Ag}^{+}$-TCE bio-actives and free $\mathrm{Ag}^{+}$ions exist. However, an increase in TCE bio-actives is expected to reduce unspent or free $\mathrm{Ag}^{+}$while elevating the reduction and nucleation of reduced $\mathrm{Ag}^{0}$ into NPs due to readily available free TCE bio-active moieties for capping. Overall, it can be argued as we increased the TCE concentration, the (i) reduction of $\mathrm{Ag}^{+}$to 
$\mathrm{Ag}^{0}$ and (ii) nucleation of $\mathrm{Ag}^{0}$ into NPs increased, whereas (iii) the growth of particles was controlled due to capping of TCE bio-actives around nascent NPs. Software (ImageJ)-based analysis of TEM images of TCE-Ag-1, TCE-Ag-2, and TCE-Ag-3 has also confirmed the TCE concentration dependent size control. Parallel ImageJ results demonstrate the average size of NPs as $10.06 \pm 0.84 \mathrm{~nm}, 4.73 \pm 1.05 \mathrm{~nm}$, and $3.48 \pm 0.28 \mathrm{~nm}$ for TCE-Ag-1 (Figure 5(Aii)), TCE-Ag-2 (Figure 5(Bii)), and TCE-Ag-3 (Figure 5(Cii)), respectively.
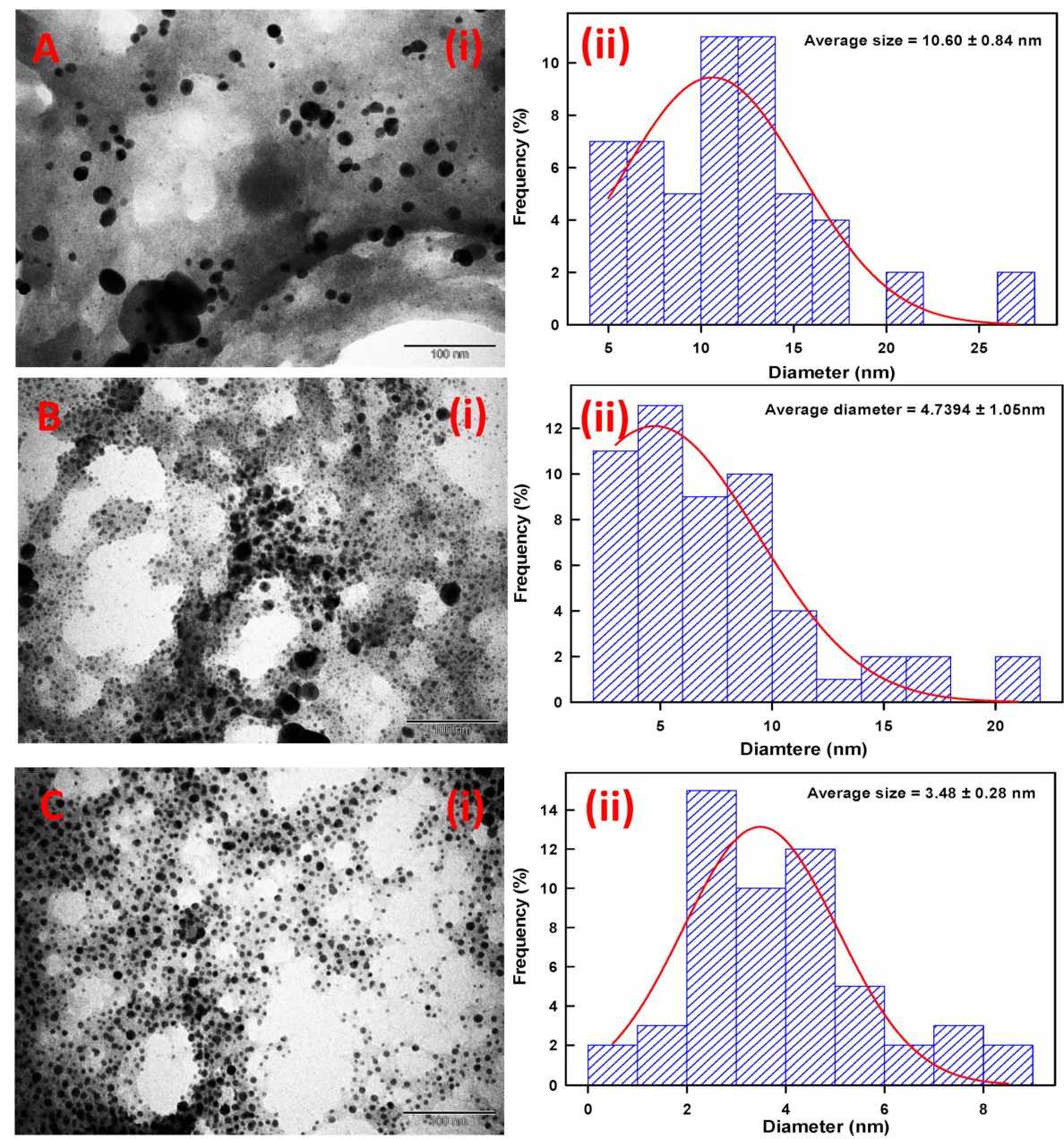

Figure 5. TEM and ImageJ-based comparative analysis of TCE-Ag-NPs. Panels (i) in (A-C) demonstrate TEM images of TCE-Ag-1, TCE-Ag-2, and TCE-Ag-3 NPs, respectively. Whereas, the histograms shown in panels (ii) in (A-C) demonstrate the average particle size and particle size distribution in the corresponding TEM images, respectively.

\subsection{Antimicrobial Activities}

3.5.1. Assessment of Size-Specific Antimicrobial Activities by Well Diffusion Assay

The antimicrobial activity of TCE-Ag-1, TCE-Ag-2, and TCE-Ag-3 were tested against MR-S. aureus (MRSA) and MDR-P. aeruginosa (MDR-PA) and C. albicans. The images in Figure 6 exhibit the zone of growth inhibition produced with the $100 \mu \mathrm{L}$ of crude formulations of TCE-Ag-1, TCE-Ag-2, and TCE-Ag-3 against test strains. The data summarized in Table 2 suggested that treatment of $100 \mu \mathrm{L}$ of TCE-Ag-1 $(10.60 \mathrm{~nm})$ formulation inhibited the growth of MRSA, MDR-PA, and C. albicans as $11.07 \pm 0.25,19.03 \pm 0.21$, and $14.17 \pm 0.06 \mathrm{~mm}$, respectively. Similarly, the diameters of growth inhibition zones with TCE-Ag-2 $(4.73 \mathrm{~nm})$ formulation were found to be $12.13 \pm 0.35,20.20 \pm 0.20$, and $15.03 \pm 0.15 \mathrm{~mm}$ against MRSA, MDR-PA, and C. albicans, respectively. The experiments with TCE-Ag-3 (3.48 nm) formulation yielded $14.23 \pm 0.15,21.13 \pm 0.15$, and $17.03 \pm 0.21 \mathrm{~mm}$ diameters against MRSA, MDR-PA, and C. albicans, respectively. Overall, the zones of 
growth inhibition reflect the size dependent antimicrobial activity of TCE-Ag NPs against both bacterial as well as fungal strains. Our findings on the size and dose dependent antibacterial activity of TCE-Ag NPs are consistent with previously published research $[53,54]$. According to the recent work by $[10,55,56]$, AgNPs synthesized by various methods have also antimicrobial action against Gram-negative and Gram-positive bacteria, as well as yeast, C. albicans. Precisely, as the size of TCE-Ag NPs decreased to $10.60 \mathrm{~nm}$ (TCE-Ag1), $>4.73 \mathrm{~nm}$ (TCE-Ag-2), and $3.48 \mathrm{~nm}$ (TCE-Ag-3), the diameter of growth inhibition increased $11.07 \pm 0.25 \mathrm{~mm},<12.13 \pm 0.35 \mathrm{~mm}$, and $<14.23 \pm 0.15 \mathrm{~mm} ; 19.03 \pm 0.21 \mathrm{~mm}$, $<20.20 \pm 0.20 \mathrm{~mm}$, and $<21.13 \pm 0.15 \mathrm{~mm}$; and $14.17 \pm 0.06 \mathrm{~mm},<15.03 \pm 0.15 \mathrm{~mm}$, and $<17.03 \pm 0.21 \mathrm{~mm}$, against MRSA, MDR-PA, and C. albicans, respectively (Table. 2). However, within bacteria, Gram-negative MDR-PA was found more sensitive against all three TCE-AgNPs formulations as compared to Gram-positive MRSA under identical conditions. However, there are no universal conclusions accepted to address the toxicity mechanism of Ag-NPs against microorganisms [57]. A Significant number of studies have claimed that $\mathrm{Ag}^{+}$released after treatment dictates Ag-NPs toxicity [58,59]. Contrarily, it has also been debated that released $\mathrm{Ag}^{+}$is not sufficient to augment toxicity induced by Ag-NPs whereas, the size, shape, surface coating, and surface charge can play an important role in influencing the extent of antimicrobial properties of nano structures [60-62].
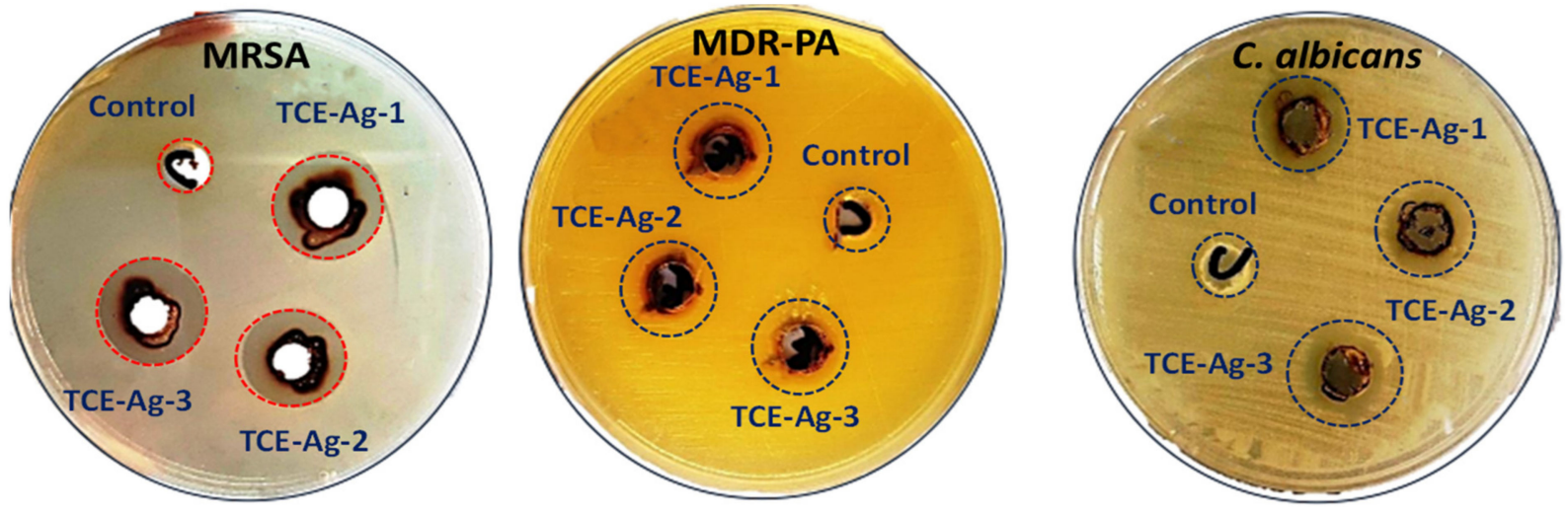

Figure 6. Comparative assessment of antimicrobial activity of TCE-Ag-1, TCE-Ag-2, and TCE-Ag-3 NPs against Gramnegative multidrug resistant $P$. aeruginosa (MDR-PA), Gram-positive methicillin resistant S. aureus (MRSA) and C. albicans cells.

Table 2. Antimicrobial activity of TCE-Ag NPs against test strains of bacteria and fungi.

\begin{tabular}{ccccc}
\hline \multirow{2}{*}{ Sr. No. } & \multirow{2}{*}{ Bacterial Strains } & \multicolumn{3}{c}{ Zone of Inhibition (mm) } \\
\cline { 3 - 5 } & & TCE-Ag-1 & TCE-Ag-2 & TCE-Ag-3 \\
\hline 1 & MR-S. aureus & $11.07 \pm 0.25$ & $12.13 \pm 0.35$ & $14 \pm 0.15$ \\
\hline 2 & MDR-P. aeruginosa & $19.03 \pm 0.21$ & $20.20 \pm 0.20$ & $21.13 \pm 0.15$ \\
\hline 3 & C. albicans & $14.17 \pm 0.06$ & $15.03 \pm 0.15$ & $17.03 \pm 0.21$ \\
\hline
\end{tabular}

3.5.2. Size-Specific MIC, MBC, and MFC Values Determination of TCE-Ag-NPs against Test Strains

The data in Table 3 described the size dependent MIC and MBC values of TCE-Ag-1 $(10.60 \mathrm{~nm})$, TCE-Ag-2 $(4.73 \mathrm{~nm})$, and TCE-Ag-3 $(3.48 \mathrm{~nm})$ NPs for cultured MRSA, MDR-PA, and C. albicans cells. At an identical concentration i.e., $100 \mu \mathrm{L}$ of TCE-Ag-1 (10.60 nm), $>$ TCE-Ag-2 $(4.73 \mathrm{~nm})$, and >TCE-Ag-3 $(3.48 \mathrm{~nm})$ NPs, MRSA, MDR-PA, and C. albicans cells grown for $24 \mathrm{~h}$ demonstrate the decrease in their MIC and MBC or MFC values with the decrease in size of NPs. Briefly, the MIC and MBC values of TCE-AgNPs having an average diameter of 10.60, 4.73, and $3.48 \mathrm{~nm}$ against Gram-positive MRSA cells grown for $24 \mathrm{~h}$ were determined to be $31.08 \pm 1.01$ and $124.33 \pm 4.04 \mu \mathrm{g} / \mathrm{mL}, 7.77 \pm 0.25$ 
and $31.08 \pm 1.01 \mu \mathrm{g} / \mathrm{mL}$, and $7.77 \pm 0.25$ and $31.08 \pm 1.01 \mu \mathrm{g} / \mathrm{mL}$, respectively (Table 3; Figure 7(Ai-Aiii)). Similarly, MIC and MBC values for Gram-negative MDR-PA were also affected by the decrease in size $(10.60>, 4.73>$, and $3.48 \mathrm{~nm})$ of TCE-Ag-1, TCE-Ag-2, and TCE-Ag-3 as $7.77 \pm 0.25$ and $15.54 \pm 0.50 \mu \mathrm{g} / \mathrm{mL}, 3.88 \pm 0.13$ and $7.77 \pm 0.25 \mu \mathrm{g} / \mathrm{mL}$, and $3.88 \pm 0.13$ and $7.77 \pm 0.25 \mu \mathrm{g} / \mathrm{mL}$, respectively (Table 3; Figure 7(Bi-Biii)). Compared to bacteria, the MIC and MFC values of TCE-Ag-1 $(10.60 \mathrm{~nm})$, TCE-Ag-2 $(4.73 \mathrm{~nm})$, and TCE-Ag-3 (3.48 nm) NPs for C. albicans were found significantly higher as $124.33 \pm 4.04$ and $248.67 \pm 8.08 \mu \mathrm{g} / \mathrm{mL}, 62.17 \pm 2.02$ and $248.67 \pm 8.08 \mu \mathrm{g} / \mathrm{mL}, 62.17 \pm 2.02$ and $124.33 \pm 4.04 \mu \mathrm{g} / \mathrm{mL}$, respectively (Table 3; Figure 7(Ci-Ciii)). The MICs and MBCs/MFCs values of AgNPs in this study are comparatively lower than those found in previous studies [10,56]. Alqahtani et al. [56] determined that biogenic AgNPs had MIC and MBC values of 39-78 $\mathrm{g} / \mathrm{mL}$ and $156-312 \mathrm{~g} / \mathrm{mL}$, respectively, against MDR-P. aeruginosa and MRSA. In another work, Ansari et al. [10] reported that green synthesized AgNPs had that MIC and MBC/MFC values of $258.3 \pm 14.4-758.3 \pm 38.2 \mu \mathrm{g} / \mathrm{mL}$ and $516.7 \pm 28.9-1533.3 \pm 57.7 \mu \mathrm{g} / \mathrm{mL}$ against MDR-PA, MRSA, and C. albicans, respectively.

Table 3. MIC and MBC/MFC * $(\mu \mathrm{g} / \mathrm{mL})$ values of TCE-AgNPs against test strains of bacteria and fungi (* indicate MFC for C. albicans).

\begin{tabular}{cccccccc}
\hline \multirow{2}{*}{ Strains } & \multicolumn{2}{c}{ TCE-Ag-1 } & \multicolumn{2}{c}{ TCE-Ag-2 } & \multicolumn{2}{c}{ TCE-Ag-3 } \\
\cline { 2 - 7 } & MIC & MBC/MFC * & MIC & MBC/MFC * & MIC & MBC/MFC * \\
\hline MRSA & $31.08 \pm 1.01$ & $124.33 \pm 4.04$ & $7.77 \pm 0.25$ & $31.08 \pm 1.01$ & $7.77 \pm 0.25$ & $31.08 \pm 1.01$ \\
\hline MDR-P. aeruginosa & $7.77 \pm 0.25$ & $15.54 \pm 0.50$ & $3.88 \pm 0.13$ & $7.77 \pm 0.25$ & $3.88 \pm 0.13$ & $7.77 \pm 0.25$ \\
\hline C. albicans & $124.33 \pm 4.04$ & $248.67 \pm 8.08 *$ & $62.17 \pm 2.02$ & $248.67 \pm 8.08^{*}$ & $62.17 \pm 2.02$ & $124.33 \pm 4.04 *$ \\
\hline
\end{tabular}

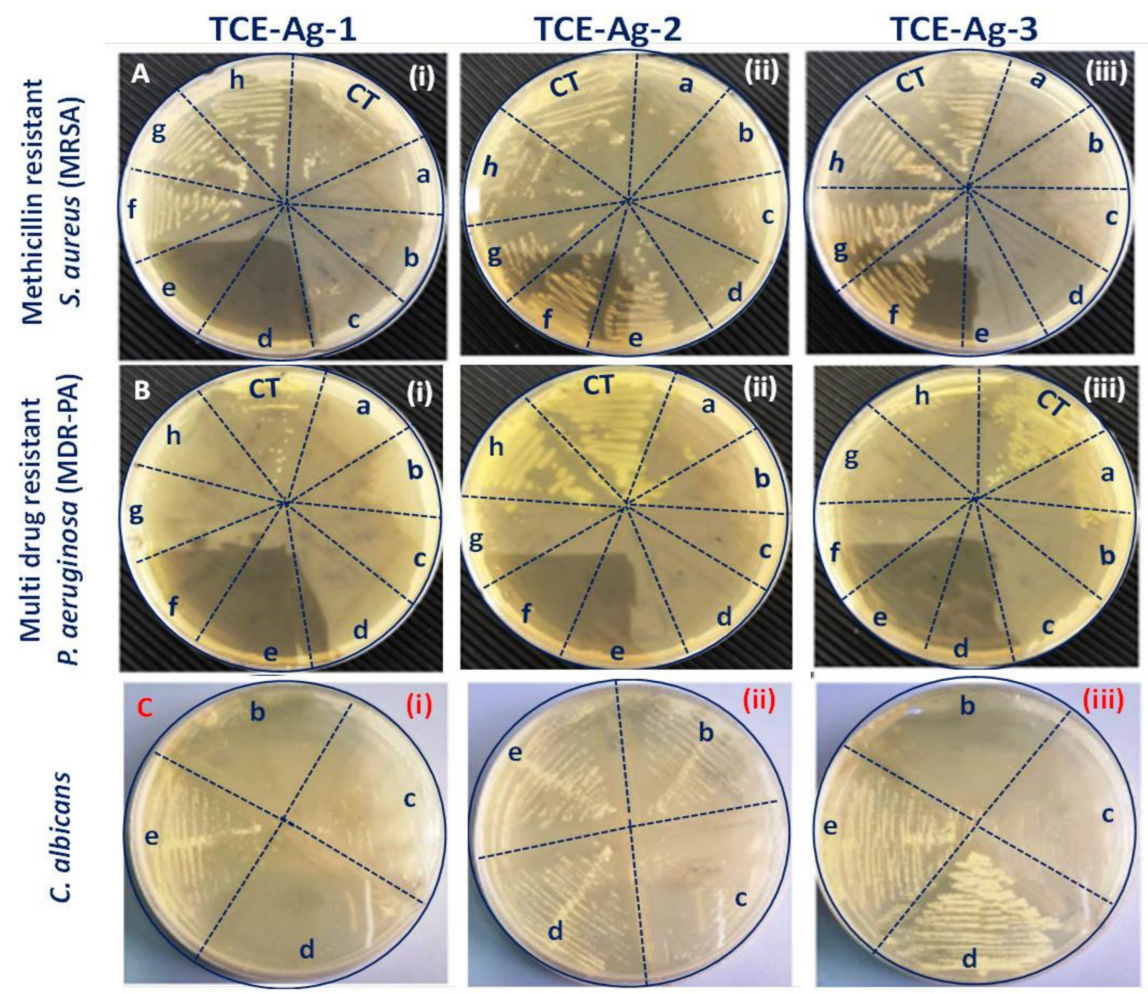

CT-Control

a-500 $\mu \mathrm{g} / \mathrm{mL}$

b- $250 \mu \mathrm{g} / \mathrm{mL}$

c- $125 \mu \mathrm{g} / \mathrm{mL}$

d-62.25 $\mu \mathrm{g} / \mathrm{mL}$

e-31.25 $\mu \mathrm{g} / \mathrm{mL}$

f-15.62 $\mu \mathrm{g} / \mathrm{mL}$

$\mathrm{g}-7.81 \mu \mathrm{g} / \mathrm{mL}$

$\mathrm{h}-3.90 \mu \mathrm{g} / \mathrm{mL}$

Figure 7. Comparative determination of MIC, MBC, and MFC values of TCE-Ag-1, TCE-Ag-2, and TCE-Ag-3 NPs against MDR-PA, MRSA, and C. albicans cells. 
3.5.3. SEM and TEM Based Analysis of the Interaction of TCE-Ag-3 with Planktonic Cells of Test Strains

To validate the obtained antimicrobial activity, we have also carried out a parallel assessment of interaction between TCE-Ag-3 NPs and test strains by SEM and TEM analyses. Owing to differences in the structure and thickness of the peptidoglycan layer between Gram-positive ( $\sim 20-80 \mathrm{~nm})$ and Gram-negative $(\sim 7-8 \mathrm{~nm})$ bacteria, TCE-Ag-3 NPs exhibited significantly greater antibacterial effect against Gram-negative MDR-PA than Gram-positive MRSA. The representative SEM images demonstrate the TCE-Ag-3 NPs induced cellular damage as deep pits and cavities in Gram-negative MDR-PA cells (Figure 8B), whereas untreated control cells sustained their native rod shape and intact cell wall (Figure 8A). TCE-Ag-3 NPs treated Gram-positive MRSA cells in Figure 8D show significant cellular damage as compared to control cells with smooth and spherical shapes (Figure 8C). The clear-cut reduced cellular damage in MRSA cells is most likely due to its rigid and three-dimensional peptidoglycan layer which is composed of peptides mediated by cross-linked polysaccharide chains [63]. The exact antimicrobial mechanism of the action of AgNPs remains unclear. It has been suggested that AgNPs could interact with the cell wall, which could lead to pits or might go deeper, into the bacterial cell, where they could influence metabolic processes i.e., by interfering with oxidative phosphorylation or forming complexes with nucleic acids [64]. It has been suggested that modifying the surface charge of AgNPs could enhance their antibacterial activity [65]. It is well known that the bacterial cell membranes have a negative charge due to the presence of various negative charge molecules such as carboxyl, amino, hydroxyl, and phosphate groups [66]. The negatively charged molecules in the cell membrane promote AgNP adhesion, making bacteria more vulnerable to antimicrobial therapy [29]. Abbaszadegan et al. [66] reported that positively charged AgNPs were attracted to negatively charged bacterial cell membranes because of electrostatic interactions, causing the positively charged nanoparticles to be adhered to the bacteria's cell wall and membranes. [66]. Furthermore, in another study, AgNPs with a negatively charged surface have been investigated and shown to be more effective in inhibiting the growth of S. aureus [64]. Therefore, it has been proposed that when these types of interactions occur, morphological changes such as cytoplasm shrinkage and membrane detachment occur, which ultimately leads to cell wall rupture and cell death as illustrated in Figures 8 and 9. Similarly, we have also evaluated the antifungal potential of TCE-Ag-3 NPs against C. albicans cells by SEM. After $24 \mathrm{~h}$ of exposure of TCE-Ag-3 NPs, the C. albicans cells showed notable alterations such as loss of native size and shapes likely due to internalization of NPs as compared to control cells which exhibited intact cell membrane and the cell wall (Figure 8E,F). The cytoplasmic volume of treated cells increased significantly with a remarkable cell membrane invagination (Figure 8 F). Similarly, the TEM based analysis of TCE-Ag-3 treated MDR-PA, MRSA, and C. albicans cells have also shown significant incorporation of NPs on the surface and cellular damage as compared to their untreated cells (Figure 9(Aii-Cii)). 

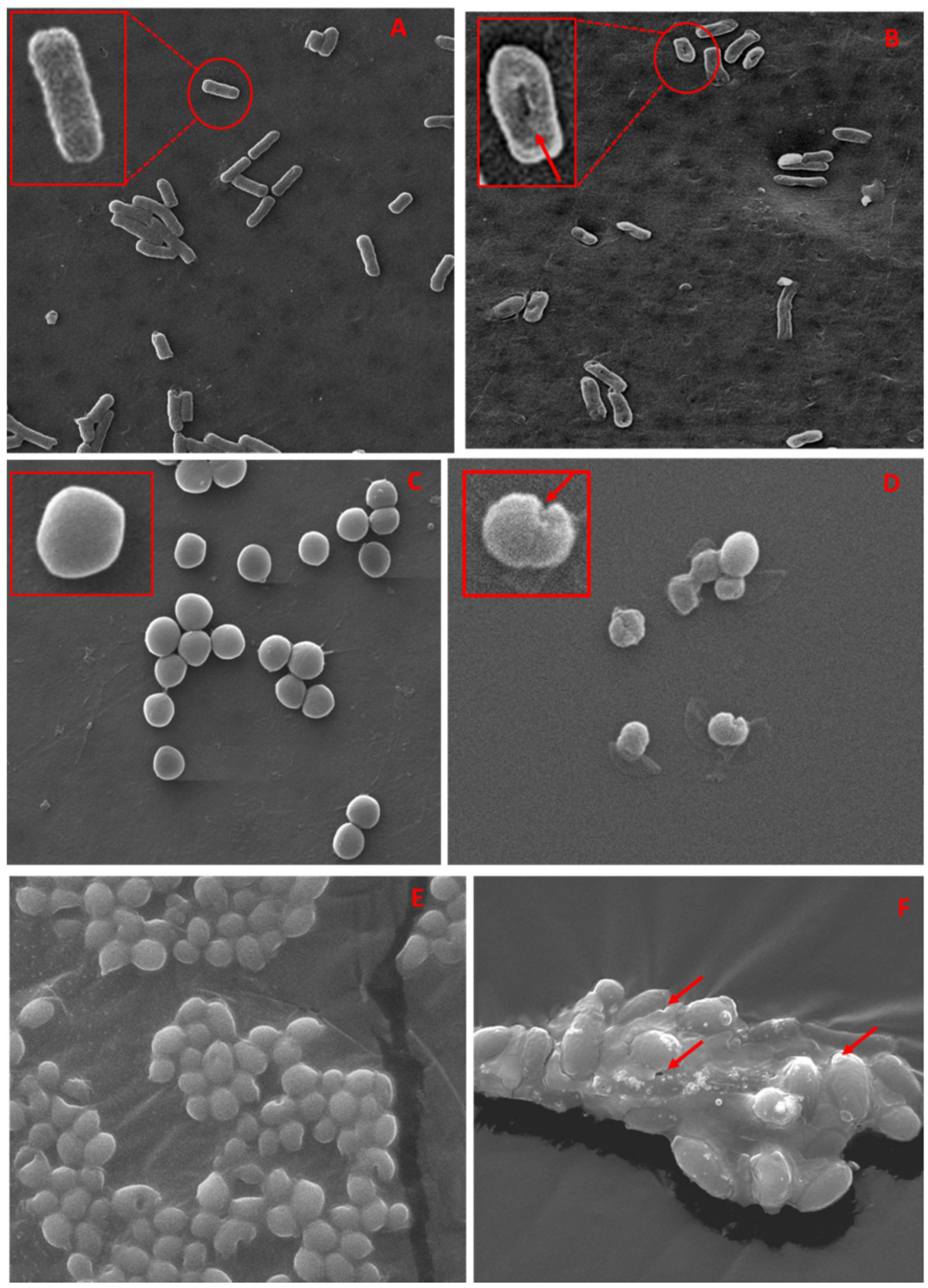

Figure 8. SEM micrographs showing morphological changes in Gram-negative multidrug resistant MDR-PA cells (A,B); Gram-positive methicillin resistant MRSA cells (C,D) and C. albicans cells (E,F), respectively, in the absence the $(\mathbf{A}, \mathbf{C}, \mathbf{E})$ and presence $(\mathbf{B}, \mathbf{D}, \mathbf{F})$ of TCE-Ag-3 NPs. 


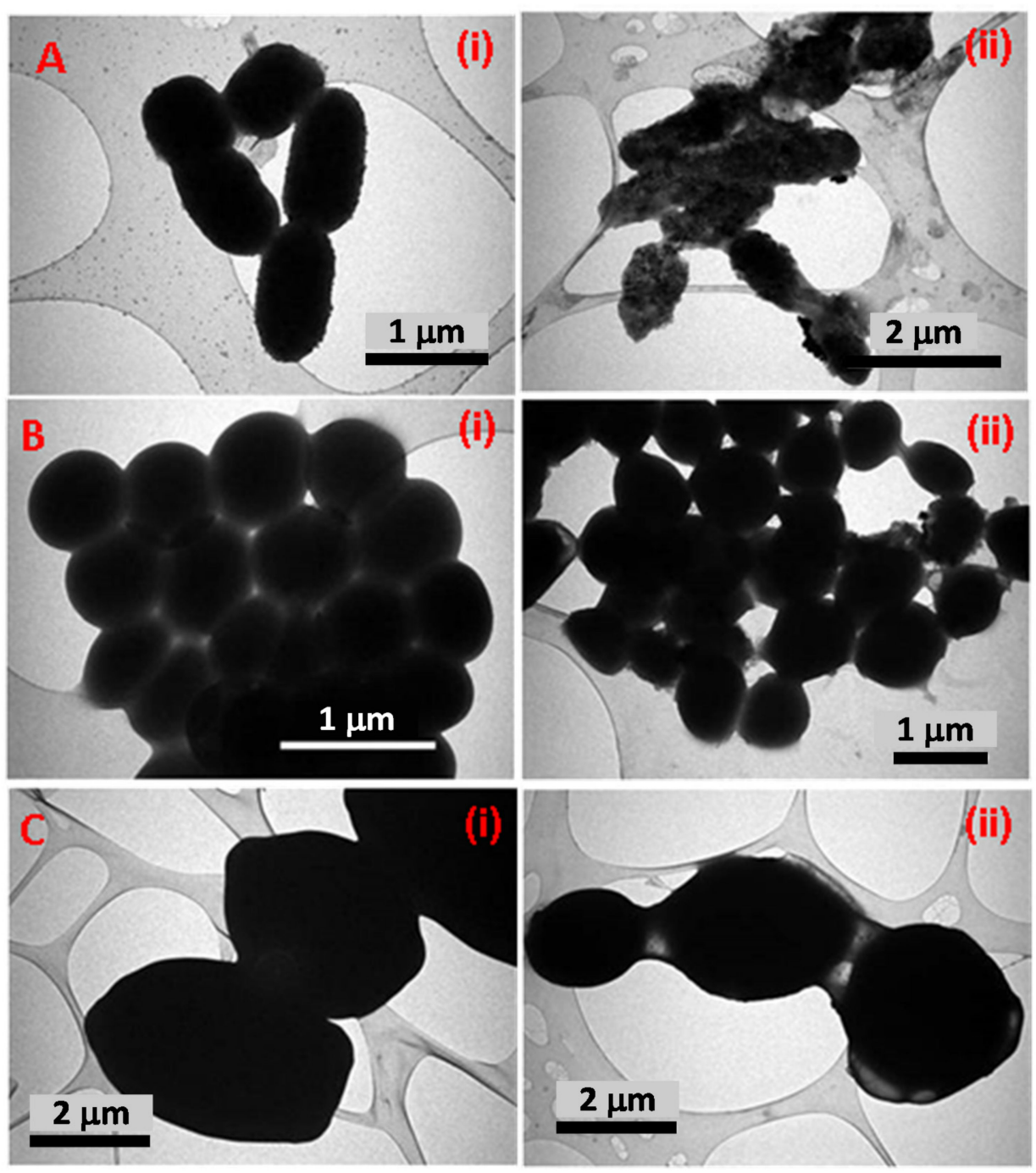

Figure 9. Shows a TEM-based comparative analysis of the interaction of TCE-Ag-3 NPs with test microbial cells. Panels (i) in (A-C) show TEM images of untreated MDR-PA, MRSA, and C. albicans cells, whereas panels (ii) in (A-C) show TEM images of MDR-PA, MRSA, and C. albicans cells treated with their MIC of TCE-Ag-3 NPs after $24 \mathrm{~h}$.

\subsubsection{Antibiofilm Activity of TCE-Ag-3 against Test Strains}

Colonization of planktonic microbial cells of bacteria and fungi eventually develops into multispecies biofilms causing the failure of a wide range of antibiotic efficacy. Precisely, harsh micro-environments of biofilms generally demonstrate a complex set of favorable conditions for prolonged biofilm survival while protecting from antimicrobial agents likely due to mechanical support of thick EPS layer around persistent microbial cells. Besides, enzymatic and acidic degradation of various antimicrobial agents has also been identified as a notorious mechanism of defence [6]. Thus, this delayed or compromised approach of microbial agents to biofilm persistent led them to develop MDR $[67,68]$. However, under said biofilm environments, a broad range of metallic NPs have been regarded as a promising alternative strategy to circumvent chronic biofilm infections. Concisely, the enhanced penetrability, high payload of drugs, stability, and post-dissolution release of metal cations in the acidic and enzymatic vicinities of biofilm matrices have generally been credited for promising antimicrobial activity of metallic nano constructs. Nevertheless, we have evaluated the antibiofilm potential of as-prepared TCE-Ag-3 nano formulations against test microorganisms in this study.

The bar graph in Figure 10 demonstrates the TCE-Ag-3 dose-dependent inhibition of biofilm formation. The data showed $58.70 \pm 0.8 \%, 65.6 \pm 1.5 \%, 66.4 \pm 0.9 \%$, and 
$75.14 \pm 1.3 \%$ reduction of biofilms formed by MDR-PA as compared to untreated control $(100 \%)$, at $0.95,1.95,3.90$, and $7.80 \mu \mathrm{g} / \mathrm{mL}$ after $24 \mathrm{~h}$ of treatment, respectively. Under identical conditions, $56.58 \pm 1.05 \%, 64.39 \pm 0.95 \%, 66.38 \pm 1.19 \%$, and $70.35 \pm 0.85 \%$; and $48.70 \pm 0.94 \%, 50.23 \pm 2.0 \%, 57.76 \pm 0.89 \%$, and $64.41 \pm 0.87 \%$ inhibition was observed in MRSA and C. albicans biofilms formation, respectively (Figure 10). Both, the bacterial and fungal strains are known to be notorious biofilm producers, which complicates their management in clinical and healthcare settings. Whereas, the parallel SEM analysis carried out at $7.8 \mu \mathrm{g} / \mathrm{mL}$ of TCE-Ag-3 has demonstrated a notable destruction in biofilms of MDR-PA (Figure 11B), MRSA (Figure 11D), and C. albicans (Figure 11F) as compared to matured biofilms in their control experiments (Figure 11A,C,E). They are well-known causative agents for several health concerns in humans, beginning with mild superficial skin infections to death leading to visceral or bone infections [69]. The rapid increase in methicillin-resistance and failure of available antibiotics has made such chronic infections more challenging against conventional treatment modalities. Hence, the biofilm inhibition in TCE-Ag-3 treated experiments prompt to envision the TCE-Ag-3 NPs as a viable option for controlling biofilm related microbial infections. Indeed, the bio-actives tannins in TCE have been regarded as a potential anti-quorum sensing (QS) and biofilm controlling plant organic agent against Chromobacterium violaceum and P. aeruginosa [70]. Besides, C. albicans, a naturally occurring pathogen in the oral cavity, was found to attenuated significantly $(p<0.001)$ while causing biofilm maturation on the denture acrylic surface at $6.25 \mathrm{mg} / \mathrm{mL}$ of TCE [71]. Although, it can be conceived that there are polyphenolic TCE bio-actives which have plausibly aggravated the QS-controlled biofilm maturation against microbial biofilms.

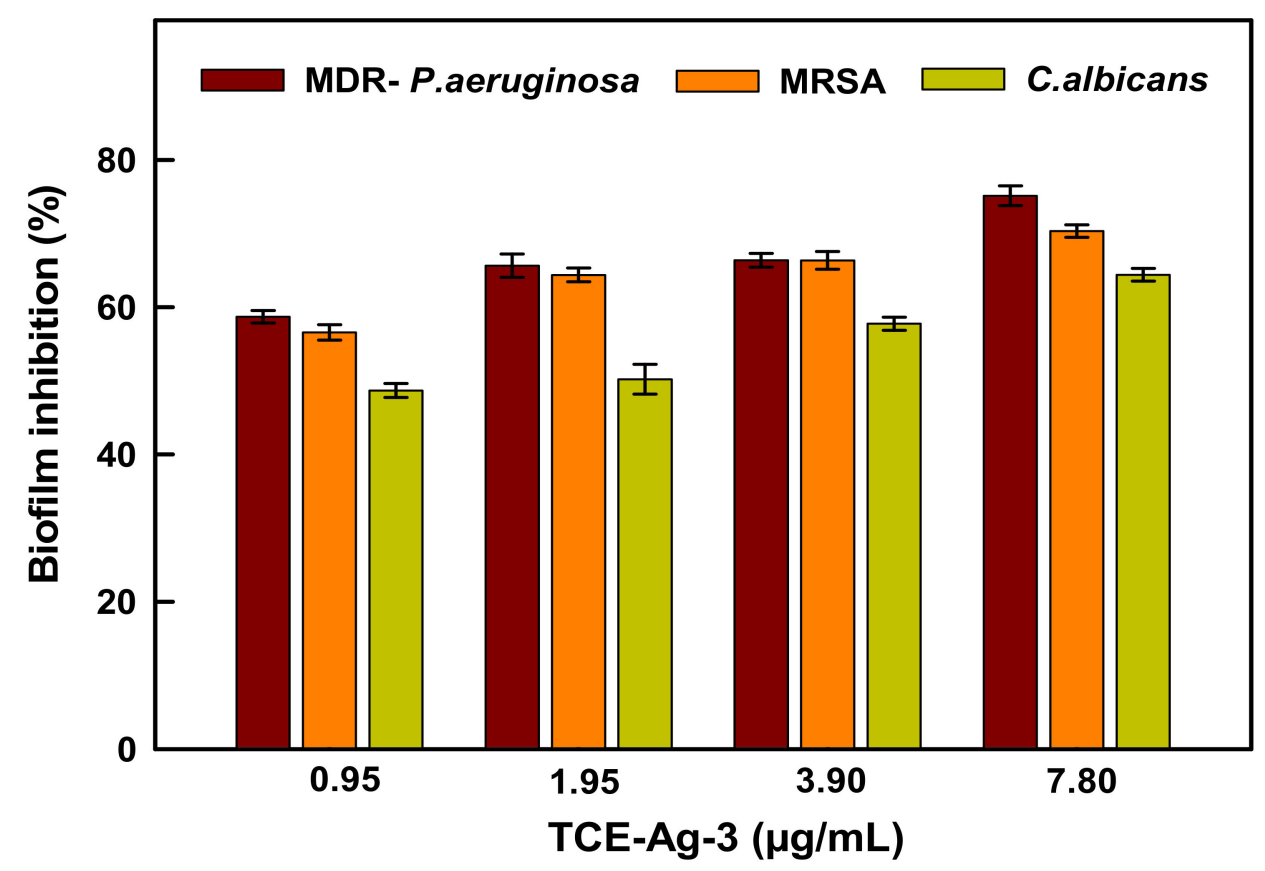

Figure 10. Reduction in the formation of biofilm in the presence of $0.95,1.95,3.90$, and $7.80 \mu \mathrm{g} / \mathrm{mL}$ concentrations of TCE-Ag-3 NPs. The error bars represent standard deviations of triplicate samples. 

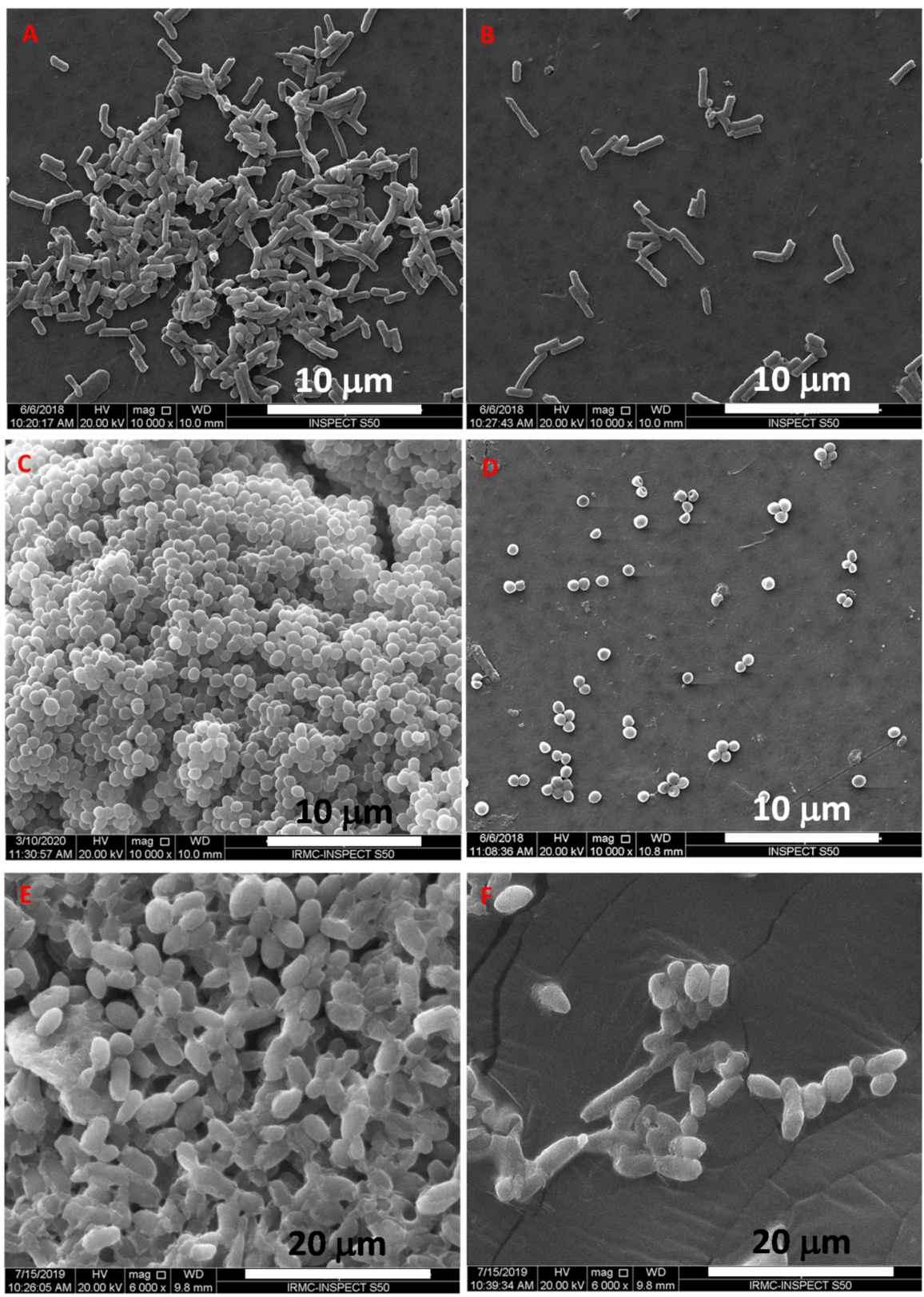

Figure 11. SEM images showed significant depletion in MDR-PA (B), MRSA (D), and C. albicans (F) biofilm formation, respectively, at $7.80 \mu \mathrm{g} / \mathrm{mL}$ of TCE-Ag-3 NPs after $24 \mathrm{~h}$ as compared to untreated experiment $(\mathbf{A}, \mathbf{C}, \mathbf{E})$.

\section{Conclusions}

The findings show that the interaction of TCE bio-actives $\mathrm{Ag}^{+}$resulted in the formation of TCE-Ag-1, TCE-Ag-2, and TCE-Ag-3 nano formulations through a simple, fast, cost-effective, and environmentally friendly path. The advantage of green synthesis of AgNPs based on plant extracts is that it contributes to environmental and human health protection by reducing the use of harmful and hazardous chemicals. The spectroscopic based art-of-the-techniques including UV-vis, FTIR, and Raman spectroscopy presented a three-tier confirmation of the involvement of TCE bio-actives in (i) $\mathrm{Ag}^{+}$reduction into Ag-NPs, (ii) controlling the particle's size, and (iii) stabilization of nascent particles by forming soft corona around NPs. In this study, the plant-derived TCE-AgNPs showed strong broad-spectrum antimicrobial and antibiofilm activity against different clinically important human pathogens such as MDR-PA, MRSA, and C. albicans at lower concentrations, suggesting that they could be used to treat infections caused by these biofilm-forming 
drug resistant organisms. Current antibiotics, as well as the antibiotic idea of combating pathogens, are increasingly becoming ineffective against new strains of existing pathogens and disease-causing species. High-throughput nanotechnology curated antimicrobials offer a novel approach to treating microbial pathogens and biofilms that are resistant to existing treatments. Because of the increasing number of AgNPs applications, more research is required to understand the toxicity and fate of AgNPs in ecosytems, as well as the related toxicity and safety issues, in order to ensure the safe use of AgNPs.

Author Contributions: M.A.A. and A.K. conceptualized and performed the experiments. A.G.A.S., M.N.A., S.A. (Sami AlYahya), M.K.A., S.S. and S.A. (Saad Alghamdi) analyzed the data of the experiments. S.A. (Sultan Akhtar) performed Electron microscopy experiments. H.D.A., S.F.A., M.K. and M.R.H. performed the statistical analysis and validated the results. M.A.A. and A.K. as research supervisors were involved in planning, execution and contributed reagents/ materials to carry out the experiments. All authors have read and agreed to the published version of the manuscript.

Funding: The authors extend their appreciation to the Deputyship for Research and Innovation, "Ministry of Higher Education" in Saudi Arabia for funding this research work through the Project number IFKSURG-2020-142.

Institutional Review Board Statement: Not applicable.

Informed Consent Statement: Not applicable.

Data Availability Statement: The data presented in this study are available in this manuscript.

Acknowledgments: The authors thanks to Research Center for Advanced Materials Science (RCAMS), King Khalid University, Abha, Saudi Arabia, and Institute for Research and Medical Consultation (IRMC), Imam Abdulrahman Fin Faisal University, Dammam, Saudi Arabia, providing technical, administrative support and facilities to carry out the research work.

Conflicts of Interest: The authors declare no conflict of interest.

\section{References}

1. Bühl, M.; Peter, S.; Willmann, M. Prevalence and risk factors associated with colonization and infection of extensively drugresistant Pseudomonas aeruginosa: A systematic review. Expert Rev. Anti-Infect. Ther. 2015, 13, 1159-1170. [CrossRef]

2. Cui, H.; Zhang, C.; Li, C.; Lin, L. Inhibition mechanism of cardamom essential oil on methicillin-resistant Staphylococcus aureus biofilm. LWT 2020, 122, 109057. [CrossRef]

3. Firacative, C. Invasive fungal disease in humans: Are we aware of the real impact? Memórias Inst. Oswaldo Cruz 2020, 115. [CrossRef] [PubMed]

4. Zuo, T.; Zhan, H.; Zhang, F.; Liu, Q.; Tso, E.Y.; Lui, G.C.; Chen, N.; Li, A.; Lu, W.; Chan, F.K.; et al. Alterations in Fecal Fungal Microbiome of Patients With COVID-19 During Time of Hospitalization until Discharge. Gastroenterology 2020, 159, 1302-1310. [CrossRef] [PubMed]

5. Sheppard, D.C.; Howell, P.L. Biofilm Exopolysaccharides of Pathogenic Fungi: Lessons from Bacteria. J. Biol. Chem. 2016, 291, 12529-12537. [CrossRef]

6. Jiang, Y.; Geng, M.; Bai, L. Targeting Biofilms Therapy: Current Research Strategies and Development Hurdles. Microorganisms 2020, 8, 1222. [CrossRef] [PubMed]

7. Limoli, D.; Jones, C.J.; Wozniak, D.J. Bacterial Extracellular Polysaccharides in Biofilm Formation and Function. Microbiol. Spectr. 2015, 3, 223-247. [CrossRef]

8. Ali, K.; Ahmed, B.; Dwivedi, S.; Saquib, Q.; Al-Khedhairy, A.; Musarrat, J. Microwave Accelerated Green Synthesis of Stable Silver Nanoparticles with Eucalyptus globulus Leaf Extract and Their Antibacterial and Antibiofilm Activity on Clinical Isolates. PLoS ONE 2015, 10, e0131178. [CrossRef] [PubMed]

9. Ali, S.G.; Ansari, M.A.; Jamal, Q.M.S.; Almatroudi, A.; Alzohairy, M.A.; Alomary, M.N.; Rehman, S.; Mahadevamurthy, M.; Jalal, M.; Khan, H.M.; et al. Butea monosperma seed extract mediated biosynthesis of ZnO NPs and their antibacte-rial, antibiofilm and anti-quorum sensing potentialities. Arab. J. Chem. 2021, 14, 103044. [CrossRef]

10. Ansari, M.A.; Asiri, S.M.M.; Alzohairy, M.A.; Alomary, M.N.; Almatroudi, A.; Khan, F.A. Biofabricated Fatty Ac-ids-Capped Silver Nanoparticles as Potential Antibacterial, Antifungal, Antibiofilm and Anticancer Agents. Pharmaceuticals 2021, 14, 139. [CrossRef]

11. Alomary, M.N.; Mohammad, A.A. Proanthocyanins-capped biogenic $\mathrm{TiO}_{2}$ nanoparticles with en-hanced penetration, antibacterial and ROS mediated inhibition of bacteria proliferation and biofilm formation: A comparative approach. Chem. Eur. J. 2021, 27, 5817-5829. [CrossRef] 
12. Murali, M.; Anandan, S.; Ansari, M.A.; Alzohairy, M.A.; Alomary, M.N.; Asiri, S.M.M.; Almatroudi, A.; Thriveni, M.C.; Singh, S.B.; Gowtham, H.G.; et al. Genotoxic and Cytotoxic Properties of Zinc Oxide Nanoparticles Phy-to-Fabricated from the Obscure Morning Glory Plant Ipomoea obscura (L.) Ker Gawl. Molecules 2021, 26, 891. [CrossRef]

13. Lin, C.-C.; Yea-Ling, C.; Jer, M.L.; Takashi, U. Evaluation of the antioxidant and hepatoprotective activity of Terminalia catappa. Am. J. Chin. Med. 1997, 25, 153-161. [CrossRef] [PubMed]

14. Siddiqi, R.; Sayeed, S.A.; Naz, S.; Saeed, S.M.G. Antioxidant Activity of the Extracts Derived from Terminalia catappa. Biol. Sci. PJSIR 2011, 54, 93-98. [CrossRef]

15. Khan, A.A.; Kumar, V.; Singh, B.K.; Singh, R. Evaluation of Wound Healing Property of Terminalia catappa on Excision Wound Models in Wistar Rats. Drug Res. 2013, 64, 225-228. [CrossRef]

16. Ko, T.-F.; Weng, Y.-M.; Chiou, R.Y.-Y. Squalene Content and Antioxidant Activity of Terminalia catappa Leaves and Seeds. J. Agric. Food Chem. 2002, 50, 5343-5348. [CrossRef] [PubMed]

17. Lin, C.-C.; Yu-Fang, H.; Ta-Chen, L. Antioxidant and free radical scavenging effects of the tannins of Terminalia catappa L. Anticancer Res. 2001, 21, 237-243.

18. Chyau, C.-C.; Tsai, S.-Y.; Ko, P.-T.; Mau, J.-L. Antioxidant properties of solvent extracts from Terminalia catappa leaves. Food Chem. 2002, 78, 483-488. [CrossRef]

19. Rajendhiran, R.; Deivasigamani, V.; Palanisamy, J.; Masan, S.; Pitchaiya, S. Terminalia catappa and Carissa carandas assisted synthesis of $\mathrm{TiO} 2$ nanoparticles-A green synthesis approach. In Proceedings of the Materials Today: Proceedings; Elsevier BV: Amsterdam, The Netherlands, 2021; Volume 45, pp. 2232-2238.

20. Ankamwar, B. Biosynthesis of Gold Nanoparticles (Green-gold) Using Leaf Extract of Terminalia catappa. E-J. Chem. 2010, 7, 1334-1339. [CrossRef]

21. Muthulakshmi, L.; Rajini, N.; Nellaiah, H.; Kathiresan, T.; Jawaid, M.; Rajulu, A. Preparation and properties of cellulose nanocomposite films with in situ generated copper nanoparticles using Terminalia catappa leaf extract. Int. J. Biol. Macromol. 2017, 95, 1064-1071. [CrossRef] [PubMed]

22. Lembang, M.S.; Yoki, Y.; Sudirman, S.; Apriandanu, D.O.B. A facile method for green synthesis of Nd2O3 nano-particles using aqueous extract of Terminalia catappa leaf. In Proceedings of the AIP Conference Proceedings, 2023: 020093; AIP Publishing LLC: Melville, NY, USA, 2018.

23. Devadiga, A.; Shetty, K.V.; Saidutta, M. Highly stable silver nanoparticles synthesized using Terminalia catappa leaves as antibacterial agent and colorimetric mercury sensor. Mater. Lett. 2017, 207, 66-71. [CrossRef]

24. Marambio-Jones, C.; Hoek, E.M.V. A review of the antibacterial effects of silver nanomaterials and potential implications for human health and the environment. J. Nanoparticle Res. 2010, 12, 1531-1551. [CrossRef]

25. Chamakura, K.; Perez-Ballestero, R.; Luo, Z.; Bashir, S.; Liu, J. Comparison of bactericidal activities of silver nanoparticles with common chemical disinfectants. Colloids Surf. B Biointerfaces 2011, 84, 88-96. [CrossRef]

26. Crisan, C.M.; Mocan, T.; Manolea, M.; Lasca, L.I.; Tăbăran, F.-A.; Mocan, L. Review on Silver Nanoparticles as a Novel Class of Antibacterial Solutions. Appl. Sci. 2021, 11, 1120. [CrossRef]

27. Joshi, A.S.; Singh, P.; Mijakovic, I. Interactions of Gold and Silver Nanoparticles with Bacterial Biofilms: Molecular Interactions behind Inhibition and Resistance. Int. J. Mol. Sci. 2020, 21, 7658. [CrossRef] [PubMed]

28. Padnya, P.; Gorbachuk, V.; Stoikov, I. The Role of Calix[n]arenes and Pillar[n]arenes in the Design of Silver Nanoparticles: Self-Assembly and Application. Int. J. Mol. Sci. 2020, 21, 1425. [CrossRef] [PubMed]

29. Pal, S.; Tak, Y.K.; Song, J.M. Does the Antibacterial Activity of Silver Nanoparticles Depend on the Shape of the Nanoparticle? A Study of the Gram-Negative Bacterium Escherichia coli. Appl. Environ. Microbiol. 2007, 73, 1712-1720. [CrossRef]

30. Shahverdi, A.R.; Fakhimi, A.; Shahverdi, H.R.; Minaian, S. Synthesis and effect of silver nanoparticles on the antibacterial activity of different antibiotics against Staphylococcus aureus and Escherichia coli. Nanomed. Nanotechnol. Biol. Med. 2007, 3, 168-171. [CrossRef]

31. Jalal, M.; Ansari, M.A.; Ali, S.G.; Khan, H.M.; Eldaif, W.A.H.; Alrumman, S.A. Green synthesis of silver nanoparticles using leaf extract of Cinnamomum tamala and its antimicrobial activity against clinical isolates of bacteria and fungi. Int. J. Adv. Res. 2016, 4, 428-440. [CrossRef]

32. Cherian, T.; Ali, K.; Fatima, S.; Saquib, Q.; Ansari, S.M.; Alwathnani, H.A.; Al-Khedhairy, A.A.; Al-Shaeri, M.; Musarrat, J. Myristica fragrans bioactive ester functionalized $\mathrm{ZnO}$ nanoparticles exhibit antibacterial and antibiofilm activities in clinical isolates. J. Microbiol. Methods 2019, 166, 105716. [CrossRef]

33. Ansari, M.A.; Khan, H.M.; Alzohairy, M.A.; Jalal, M.; Ali, S.G.; Pal, R.; Musarrat, J. Green synthesis of $\mathrm{Al}_{2} \mathrm{O}_{3}$ nanoparticles and their bactericidal potential against clinical isolates of multi-drug resistant Pseudomonas aeruginosa. World J. Microbiol. Biotechnol. 2014, 31, 153-164. [CrossRef] [PubMed]

34. Klaus, T.; Joerger, R.; Olsson, E.; Granqvist, C.-G. Silver-based crystalline nanoparticles, microbially fabricated. Proc. Natl. Acad. Sci. USA 1999, 96, 13611-13614. [CrossRef]

35. Ahmad, A.; Mukherjee, P.; Senapati, S.; Mandal, D.; Khan, M.I.; Kumar, R.; Sastry, M. Extracellular biosynthesis of silver nanoparticles using the fungus Fusarium oxysporum. Colloids Surf. B Biointerfaces 2003, 28, 313-318. [CrossRef]

36. Borse, S.; Murthy, Z.V.P.; Kailasa, S.K. Chicken egg white mediated synthesis of platinum nanoclusters for the selective detection of carbidopa. Opt. Mater. 2020, 107, 110085. [CrossRef] 
37. Thombre, R.; Parekh, F.; Lekshminarayanan, P.; Francis, G. Studies on antibacterial and antifungal activity of silver nanoparticles synthesized using Artocarpus heterophyllus leaf extract. Biotechnol. Bioinf. Bioeng. 2012, 2, 632-637.

38. Černík, M.; Padil, V.V.T. Green synthesis of copper oxide nanoparticles using gum karaya as a biotemplate and their antibacterial application. Int. J. Nanomed. 2013, 8, 889-898. [CrossRef]

39. Ali, K.; Dwivedi, S.; Azam, A.; Saquib, Q.; Al-Said, M.S.; Alkhedhairy, A.A.; Musarrat, J. Aloe vera extract functionalized zinc oxide nanoparticles as nanoantibiotics against multi-drug resistant clinical bacterial isolates. J. Colloid Interface Sci. 2016, 472, 145-156. [CrossRef]

40. Bobby, M.N.; Wesely, E.G.; Johnson, M. FT-IR studies on the leaves of Albizia lebbeck benth. Int. J. Pharm. Pharm. Sci. 2012, 4, 293-296.

41. Parlinska-Wojtan, M.; Kus-Liskiewicz, M.; Depciuch, J.; Sadik, O. Green synthesis and antibacterial effects of aqueous colloidal solutions of silver nanoparticles using camomile terpenoids as a combined reducing and capping agent. Bioprocess Biosyst. Eng. 2016, 39, 1213-1223. [CrossRef] [PubMed]

42. Moskovits, M. Surface-enhanced spectroscopy. Rev. Mod. Phys. 1985, 57, 783. [CrossRef]

43. Jurasekova, Z.; Garcia-Ramos, J.V.; Domingo, C.; Sanchez-Cortes, S. Surface-enhanced Raman scattering of flavonoids. J. Raman Spectrosc. 2006, 37, 1239-1241. [CrossRef]

44. Garcia-Bucio, M.A.; Maynez-Rojas, M.Á.; Casanova-González, E.; Cárcamo-Vega, J.J.; Ruvalcaba-Sil, J.L.; Mitrani, A. Raman and surface-enhanced Raman spectroscopy for the analysis of Mexican yellow dyestuff. J. Raman Spectrosc. 2019, 50, 1546-1554. [CrossRef]

45. Oyeleye, S.I.; Adebayo, A.A.; Ogunsuyi, O.B.; Dada, F.A.; Oboh, G. Phenolic profile and Enzyme Inhibitory activities of Almond (Terminalia catappa) leaf and Stem bark. Int. J. Food Prop. 2017, 20, S2810-S2821. [CrossRef]

46. Jones, R.S.; Parker, M.D.; Morris, M.E. Quercetin, Morin, Luteolin, and Phloretin Are Dietary Flavonoid Inhibitors of Monocarboxylate Transporter 6. Mol. Pharm. 2017, 14, 2930-2936. [CrossRef]

47. Wijeratne, S.S.K.; Abou-Zaid, M.M.; Shahidi, F. Antioxidant Polyphenols in Almond and Its Coproducts. J. Agric. Food Chem. 2006, 54, 312-318. [CrossRef]

48. Harnly, J.M.; Doherty, R.F.; Beecher, G.R.; Holden, J.M.; Haytowitz, D.B.; Bhagwat, A.S.; Gebhardt, S. Flavonoid Content of U.S. Fruits, Vegetables, and Nuts. J. Agric. Food Chem. 2006, 54, 9966-9977. [CrossRef] [PubMed]

49. Siess, M.H.; Le Bon, A.M.; Canivenc-Lavier, M.C.; Amiot, M.J.; Sabatier, S.; Aubert, S.Y.; Suschetet, M. Flavonoids of Honey and Propolis: Characterization and Effects on Hepatic Drug-Metabolizing Enzymes and Benzo[a]pyrene-DNA Binding in Rats. J. Agric. Food Chem. 1996, 44, 2297-2301. [CrossRef]

50. Biswas, N.; Kapoor, S.; Mahal, H.S.; Mukherjee, T. Adsorption of CGA on colloidal silver particles: DFT and SERS study. Chem. Phys. Lett. 2007, 444, 338-345. [CrossRef]

51. Kora, A.J.; Arunachalam, J. Green fabrication of silver nanoparticles by gum Tragacanth (Astragalus gummifer): A dual func-tional reductant and stabilizer. J. Nanomater. 2012, 1, 69. [CrossRef]

52. Ranoszek-Soliwoda, K.; Tomaszewska, E.; Małek, K.; Celichowski, G.; Orlowski, P.; Krzyzowska, M.; Grobelny, J. The synthesis of monodisperse silver nanoparticles with plant extracts. Colloids Surf. B Biointerfaces 2019, 177, 19-24. [CrossRef] [PubMed]

53. Korshed, P.; Li, L.; Liu, Z.; Mironov, A.; Wang, T. Size-dependent antibacterial activity for laser-generated silver nano-particles. J. Interdiscip. Nanomed. 2019, 4, 24-33. [CrossRef]

54. Skomorokhova, E.A.; Sankova, T.P.; Orlov, I.A.; Savelev, A.N.; Magazenkova, D.N.; Pliss, M.G.; Skvortsov, A.N.; Sosnin, I.M.; Kirilenko, D.A.; Grishchuk, I.V.; et al. Size-Dependent Bioactivity of Silver Nanoparticles: Antibacterial Properties, Influence on Copper Status in Mice, and Whole-Body Turnover. Nanotechnol. Sci. Appl. 2020, 13, 137-157. [CrossRef] [PubMed]

55. Loo, Y.Y.; Rukayadi, Y.; Nor-Khaizura, M.-A.-R.; Kuan, C.H.; Chieng, B.W.; Nishibuchi, M.; Radu, S. In Vitro Antimicrobial Activity of Green Synthesized Silver Nanoparticles against Selected Gram-negative Foodborne Pathogens. Front. Microbiol. 2018, 9, 1555. [CrossRef]

56. Alqahtani, M.A.; Al Othman, M.R.; Mohammed, A.E. Bio fabrication of silver nanoparticles with antibacterial and cytotoxic abilities using lichens. Sci. Rep. 2020, 10, 1-17.

57. Tolaymat, T.M.; El Badawy, A.M.; Genaidy, A.; Scheckel, K.; Luxton, T.P.; Suidan, M. An evidence-based environmental perspective of manufactured silver nanoparticle in syntheses and applications: A systematic review and critical appraisal of peer-reviewed scientific papers. Sci. Total. Environ. 2010, 408, 999-1006. [CrossRef] [PubMed]

58. Navarro, E.; Piccapietra, F.; Wagner, B.; Marconi, F.; Kaegi, R.; Odzak, N.; Sigg, L.; Behra, R. Toxicity of Silver Nanoparticles to Chlamydomonas reinhardtii. Environ. Sci. Technol. 2010, 42, 8959-8964. [CrossRef] [PubMed]

59. Miao, A.J.; Schwehr, K.A.; Xu, C.; Zhang, S.J.; Luo, Z.; Quigg, A.; Santschi, P.H. The algal toxicity of silver engineered nanoparticles and detoxification by exopolymeric substances. Environ. Pollut. 2008, 157, 3034-3041. [CrossRef] [PubMed]

60. Fabrega, J.; Fawcett, S.R.; Renshaw, J.C.; Lead, J.R. Silver nanoparticle impact on bacterial growth: Effect of pH, concentration, and organic matter. Environ. Sci. Technol. 2009, 43, 7285-7290. [CrossRef] [PubMed]

61. Kawata, K.; Osawa, M.; Okabe, S. In Vitro Toxicity of Silver Nanoparticles at Noncytotoxic Doses to HepG2 Human Hepatoma Cells. Environ. Sci. Technol. 2009, 43, 6046-6051. [CrossRef]

62. Sotiriou, G.A.; Teleki, A.; Camenzind, A.; Krumeich, F.; Meyer, A.; Panke, S.; Pratsinis, S.E. Nanosilver on nanostructured sili-ca: Antibacterial activity and Ag surface area. Chem. Eng. J. 2011, 170, 547-554. [CrossRef] [PubMed] 
63. Wang, W.-X.; Geng, L.; Ding, S.; Xu, S.-K. Facile Synthesis of Silver Nanoparticles and their Antimicrobial Activity against Several Representative Microbial Species. In Proceedings of the 2012 International Conference on Biomedical Engineering and Biotechnology, Macau, Macao, 28-30 May 2012; Institute of Electrical and Electronics Engineers (IEEE): Washington, DC, USA, 2012; pp. 287-290.

64. Tormena, R.P.; Rosa, E.V.; Mota, B.D.; Chaker, J.A.; Fagg, C.W.; Freire, D.O.; Martins, P.M.; da Silva, I.C.; Sousa, M.H. Evaluation of the antimicrobial activity of silver nanoparticles obtained by microwave-assisted green synthesis using Handroanthus impe-tiginosus (Mart. ex DC.) Mattos underbark extract. RSC Adv. 2020, 10, 20676-20681. [CrossRef]

65. Mandal, D.; Dash, S.K.; Das, B.; Chattopadhyay, S.; Ghosh, T.; Das, D.; Roy, S. Bio-fabricated silver nanoparticles preferentially targets Gram positive depending on cell surface charge. Biomed. Pharmacother. 2016, 83, 548-558. [CrossRef] [PubMed]

66. Abbaszadegan, A.; Ghahramani, Y.; Gholami, A.; Hemmateenejad, B.; Dorostkar, S.; Nabavizadeh, M.; Sharghi, H. The effect of charge at the surface of silver nanoparticles on antimicrobial activity against gram-positive and gram-negative bacteria: A preliminary study. J. Nanomater. 2015, 16, 53. [CrossRef]

67. Mohanta, Y.K.; Biswas, K.; Jena, S.K.; Hashem, A.; Allah, E.F.A.; Mohanta, T.K. Anti-biofilm and Antibacterial Activities of Silver Nanoparticles Synthesized by the Reducing Activity of Phytoconstituents Present in the Indian Medicinal Plants. Front. Microbiol. 2020, 11, 1143. [CrossRef] [PubMed]

68. Pacios, O.; Blasco, L.; Bleriot, I.; Fernandez-Garcia, L.; González Bardanca, M.; Ambroa, A.; Tomás, M. Strategies to combat multidrug-resistant and persistent infectious diseases. Antibiotics 2020, 9, 65. [CrossRef] [PubMed]

69. Cucarella, C.; Tormo-Mas, M.Á.; Úbeda, C.; Trotonda, M.P.; Monzón, M.; Peris, C.; Amorena, B.; Lasa, I.; Penadés, J.R. Role of Biofilm-Associated Protein Bap in the Pathogenesis of Bovine Staphylococcus aureus. Infect. Immun. 2004, 72, 2177-2185. [CrossRef] [PubMed]

70. Taganna, J.C.; Quanico, J.P.; Perono, R.M.G.; Amor, E.C.; Rivera, W.L. Tannin-rich fraction from Terminalia catappa inhibits quorum sensing (QS) in Chromobacterium violaceum and the QS-controlled biofilm maturation and LasA staphylolytic activity in Pseudomonas aeruginosa. J. Ethnopharmacol. 2011, 134, 865-871. [CrossRef]

71. Machado-Gonçalves, L.; Tavares-Santos, A.; Santos-Costa, F.; Soares-Diniz, R.; Carvalho-Galvão, L.C.-D.; Sousa, E.M.-D.; BeninniPaschoal, M.-A. Effects of Terminalia catappa Linn. Extract on Candida albicans biofilms developed on denture acrylic resin discs. J. Clin. Exp. Dent. 2018, 10, e642-e647. [CrossRef] 